\title{
Long-Term Trends in Marriage Timing and the Impact of Migration, the Netherlands (1650-1899)
}

Charlotte Störmer, Corry Gellatly, Anita Boele \& Tine de Moor

To cite this article: Störmer, C., Gellatly, C., Boele, A., \& De Moor, T. (2017). Long-Term Trends in Marriage Timing and the Impact of Migration, the Netherlands (1650-1899). Historical Life Course Studies, 6, 40-68. http://hdl.handle. net/10622/23526343-2017-0012?locatt=view:master

\section{HISTORICAL LIFE COURSE STUDIES}

Urban-rural dichotomies in historical demography

VOLUME 6, SPECIAL ISSUE 1 2018

GUEST EDITORS

Christa Matthys Saskia Hin Jan Kok Richard Paping 


\section{HISTORICAL LIFE COURSE STUDIES}

Historical Life Course Studies is the electronic journal of the European Historical Population Samples Network (EHPSNet). The journal is the primary publishing outlet for research involved in the conversion of existing European and nonEuropean large historical demographic databases into a common format, the Intermediate Data Structure, and for studies based on these databases. The journal publishes both methodological and substantive research articles.

\section{Methodological Articles}

This section includes methodological articles that describe all forms of data handling involving large historical databases, including extensive descriptions of new or existing databases, syntax, algorithms and extraction programs. Authors are encouraged to share their syntaxes, applications and other forms of software presented in their article, if pertinent, on the EHPS-Net website.

\section{Research articles}

This section includes substantive articles reporting the results of comparative longitudinal studies that are demographic and historical in nature, and that are based on micro-data from large historical databases.

Historical Life Course Studies is a no-fee double-blind, peer-reviewed open-access journal supported by the European Science Foundation (ESF, http://www.esf.org), the Scientific Research Network of Historical Demography (FWO Flanders, http://www.historicaldemography.be) and the International Institute of Social History Amsterdam (IISH, http:// socialhistory.org/). Manuscripts are reviewed by the editors, members of the editorial and scientific boards, and by external reviewers. All journal content is freely available on the internet at http://www.ehps-net.eu/journal.

Editors: Koen Matthijs \& Paul Puschmann

Family and Population Studies

KU Leuven, Belgium

hislives@kuleuven.be

The European Science Foundation (ESF) provides a platform for its Member Organisations to advance science and explore new directions for research at the European level. Established in 1974 as an independent non-governmental organisation, the ESF currently serves 78 Member Organisations across 30 countries. EHPS-Net is an ESF Research Networking Programme.

The European Historical Population Samples Network (EHPS-net) brings together scholars to create a common format for databases containing non-aggregated information on persons, families and households. The aim is to form an integrated and joint interface between many European and non-European databases to stimulate comparative research on the micro-level.

Visit: http://www.ehps-net.eu.
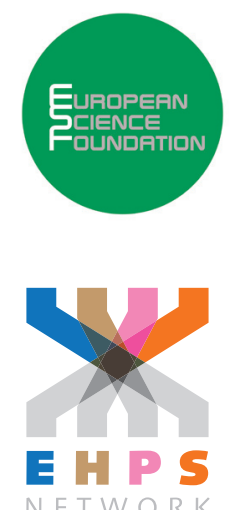


\title{
Long-Term Trends in Marriage Timing and the Impact of Migration, the Netherlands (1650-1899)
}

\author{
Charlotte Störmer \\ Corry Gellatly \\ Anita Boele \\ Tine de Moor \\ Utrecht University
}

\section{ABSTRACT}

The features of historical marriage patterns have been linked to debates in social and economic history about economic growth and female agency. However, there is a lack of empirical evidence on the demographics of marriage prior to the nineteenth century. Here, we study trends in sex-specific ages at first marriage, regional variation and the impact of migration on marital timing in the Netherlands in the period 1650-1900. We make use of two new large historical datasets, namely an aggregation of Dutch genealogies and the transcribed marriage banns of Amsterdam. This allows us to understand the features and developments of marriage ages from a long-term perspective in what is known as one of the core-areas of the so-called European Marriage Pattern. Our results show high marriage ages for both sexes from the beginning of our study period, increasing until the mid-19th century. A closer look at regional variation reveals clear differences between the provinces and between urban and rural settings with those in the western part of the country and in urban centers marrying earlier. Migrating individuals married on average later than non-migrating individuals both compared to men and women in the receiving community, as to the 'stayers' in the location of origin. As later marriage implies a reduction of the window of fertility, especially for women, our results suggest that migration and increasing regional mobility might have been an important driver of the demographic shift toward higher marriage ages and lower fertility in Europe between the $17^{\text {th }}$ and $19^{\text {th }}$ centuries.

Keywords: Marriage age, Sex differences, Regional variation, Migration, European marriage pattern

e-ISSN: $\quad$ 2352-6343

PID article: $\quad$ http://hdl.handle.net/10622/23526343-2017-0012?locatt=view:master

The article can be downloaded from here.

(C) 2017, Charlotte Störmer, Corry Gellatly, Anita Boele, Tine de Moor

This open-access work is licensed under a Creative Commons Attribution 4.0 International License, which permits use, reproduction \& distribution in any medium for non-commercial purposes, provided the original author(s) and source are given credit. See http://creativecommons.org/licenses/ 
In his seminal paper, Hajnal (1965) argued that the north-western regions of Europe (especially the Netherlands, Belgium and England) have been characterized by a specific marriage pattern since the early modern period - the so-called European Marriage Pattern (EMP). In these regions both males and females marry late, couples tend to start their own household as they marry (neolocality) and there is a high percentage of lifetime singles. In the past decade, the role of the EMP and related socio-demographic features have been linked to different speeds of economic development and industrialisation across Europe, and also vis-à-vis the rest of the world, whilst the emergence of the first features of the EMP have been placed into the late middle ages, therefore much further back in time than Hajnal had originally envisaged (De Moor and Van Zanden 2010). In the various contributions to the debate, the linkage between changes in economic behaviour on a micro level has been connected to changes in the composition and size of the household. Later marriage ages for both sexes, but in particular women, in combination with high shares of life-time singles among both men and women, for reduced fertility and contributed to economic growth (see however also: Dennison and Ogilvie 2014). The reduced spousal age gap that resulted from later marriage for women has also been interpreted as a trend toward increased female agency (e.g. Shorter 1975; Carmichael, de Moor, \& van Zanden, 2011; Carmichael et al. 2015).

Ongoing research continues to add new elements to our understanding of the mechanisms behind the EMP. However, there is a lack of empirical data to draw conclusions about developments in marriage ages in the pre-1850 era. We know a lot about (sex-specific) increases in marriage ages in different European countries and regions from the $19^{\text {th }}$ century onwards, but little is known about earlier developments. Most studies are based on only a limited number of parishes per country for a limited time frame (Flinn 1981). In contrast to a number of previous studies, which have focused only on female marriage age in the context of the effect of the EMP on economic development (Dennison and Ogilvie 2014), this study is one of the first to also explore male marriage age in historical Europe (1650-1899). This decision is based on the view that marriage ages of both sexes form an important dimension to any marriage pattern and have important implications for female agency and female participation in the labour market. They also have important consequences for the fertility of marriages, which we might predict will be lower when the wife (and possibly also the husband) is older.

Apart from a better understanding of changes in marriage ages of women and men (and hence spousal age gaps) over time and within regions, it is important to understand how migration of people might have affected the age at which they married. As stated, e.g. by Moch (1995), mobility played a significant role since the $17^{\text {th }}$ century in the transformation of Europe, especially as it was essential to the process of urbanization. We can, therefore, ask questions about how increased mobility was related to marital timing and the marriage market. In previous studies of marriage using reconstructed life histories from parish records, migration has been problematic for the estimation of life expectancies and average marriage ages, because this information is unknown for individuals who migrate away from the parishes (Jonker and van der Vaart 2007; for an example of a comparison of marital timing in 'leavers' and 'stayers' using local family reconstitutions see Voland \& Dunbar 1997). As such, it is important to understand to what extent those who migrate away from their birth place, either marry earlier or later compared to both the 'receiving' community and the stayers in the place of origin.

On an individual level, four outcomes of migration on marital timing are possible: 1) Migration might increase marriage ages compared to both the stayers in the place of origin and the men and women living in the receiving community because it takes time to settle down in a new (urban) environment, to become part of a social network and find a suitable partner (Lynch 1991; De Vries 1984; Van Poppel 1992; overview: Puschmann et al. 2014; Puschmann et al. 2016), or: 2) Migration might cause a lowering of marriage ages vis-à-vis stayers because of economic and demographic conditions (job opportunities, higher wages, favourable sex-ratios). Good economic conditions facilitate the establishment of one's own household, a necessary precondition for getting married in EMP-societies where neo-locality was the norm (Haines 1996; Jampaklay 2006; Cilliers 2013). In addition, migration could be used as a way to escape societal or parental control to marry earlier or the self-chosen partner (Oris 2000), or: 3) Migration has no impact. Marriage ages of migrants remain the same as in the place of origin and people bring their marriage pattern with them to new places, or, 4) Migrants adjust to the marriage patterns in the new place of residence. 
In the existing literature, there is evidence for a link between migration and marital timing, but it is not well understood yet, especially the possible link with the development of the EMP. There are several studies addressing the marriage patterns of migrants in the context of settler populations, e.g. Cilliers (2013) for the Cape Colony and Charbonneau et al. (2000) for the French-Canadians in the Québec region, but the moves to those countries, with their abundance of natural resources and opportunities for exploitation, are not representative for the type of migration that was most common in the European past, namely local migration within individuals' own countries or regions or to neighbouring European countries. Others focus on rural-to-urban migration and rarely go back in time further than the $19^{\text {th }}$ century (see e.g. review in Lynch 1991).

By studying historical developments in male and female marriage ages in the Netherlands - one of the core regions of the EMP - using two new historical data sets, we have sought to contribute to a more diversified picture of marriage ages (and patterns) ${ }^{1}$, also in the pre-1850 period, and the extent of variation in marriage ages that were seen between Dutch regions and over time and the impact of migration. For those marriages in our data sets, where the place of birth was known for either one or both of the spouses, we have examined whether they were marrying in the place of their birth (baptism), or whether they had migrated to the marriage place. The resulting migration proxy was used to compare marriage ages of staying and migrating fractions of the population. To what extent did marriage ages of migrants differ from those of local couples in the receiving community and the stayers at the place of origin? By extending our analyses to the relative proportion of males and females who migrated from their place of birth and marry at another place, we add to the current debate through an indication of the extent of mobility of women prior to marriage, relative to men and the impact of migration on marriage ages. The structure of genealogical data is such that we have only information about the place of birth and place of marriage, so we do not know when people actually migrated. However, we are able to differentiate between the direction of migration (urban-rural, eastwest) and marital timing to discern historical demographic differences in marriage age. In the future, the conclusions of our exploratory and descriptive analyses can be deepened and tested further.

\section{DATA SOURCES}

We make use of two new and very different sources of historical family information for this study: family tree genealogies and information from the Amsterdam marriage banns. These data are quite different in format and features and we address these as well as the origins of these data sets in the following sections.

\subsection{FAMILY TREE GENEALOGIES (DUTCH GENEALOGICAL DATA)}

A problem with previous studies of marriage age, particularly prior to the nineteenth century, are the small sample sizes. To obtain larger amounts of data, we adopted the approach of crowd-sourcing genealogical data (Gellatly 2015). The advantages of this type of data is that it can give us a broader chronological and geographical coverage, by using the large amounts of genealogical data that have been collected and collated by individuals researching their family trees. However, there are disadvantages of using genealogical data based on trees of ascendants, for example, they tend to show a bias toward larger and longer-lived families and married couples who had children (Hacker 2010; Zhao 2001). Also, people without a direct line of descent to future generations are less likely to be found by genealogists who primarily investigate their line of descent from the past. As will be discussed below, the differences in results between the two data sets especially regarding the female marriage ages suggest that also in our genealogical data set fertile couples are overrepresented. We return to this point in the discussion of the relationship between migration, marriage ages and fertility levels.

$1 \quad$ As our data collection is primarily focused on marriage ages and spousal age gaps, we do not intend to capture a comprehensive picture of marriage patterns (as this also includes other factors such as the proportion of singles and patterns of residence) in the study populations but we will use these essential features as indicators of the marriage pattern. 
The genealogical database (compiled from the 924 selected genealogical data files) contained ca. 0.94 million marriage events, ca. 2.5 million birth events, ca. 1.5 million death events and ca. 0.96 million other events, for which there was place name information. These place names consisted of ca. 174,000 unique character strings (many of which were simply variations on the same place, e.g. "Amsterdam, Netherlands" and "Amsterdam, NL". The priority for geocoding was to code those place name character strings which applied to the most events. There were 145,636 place name character strings that applied to only one event, and 14,208 that applied to two events. In total, we geocoded 40,614 place name character strings, including all that applied to three or more events. This resulted in 4,930,265 geocoded places. This database was then further refined with extraction of data sets for this study.

After removal of duplicate marriages - which were identified through a comparison of the first seven letters of each spouse's surname and the marriage year - the data was filtered for marriages that occurred between 1650 and 1899, where the focal spouse was over the age of 13 at marriage, the place of marriage was in the Netherlands and had been checked and geocoded. ${ }^{2}$ As an additional filter, we only included marriages where the lifespan of the focal spouse was $<111$, and where no estimated dates were used to calculate the lifespan. This step was intended to ensure that the level of research carried out on the marrying individual was comprehensive. The final data set comprised 187,957 marriages for men and 185,523 marriages for women.

In this paper, we focus on marriage ages in first marriages only, meaning that only those individuals that were married for the first time are included (irrespective of later remarriages of the individuals). This selection was chosen to reduce the possible impact of partner selection and marital timing effects related to remarriages.

In the case of the genealogical data, we only know whether the individual has previously been married if we have a date for another marriage in which they appeared, whilst we excluded all marriages of individuals where we could not tell whether another marriage occurred before or after, because the date of the other marriage was unknown.

Given that the data set was fully geocoded, we are able to take a closer look at marriage patterns across the Netherlands, broken down by province. A sub-sample of Amsterdam allowed us to make comparisons with the data from the marriage banns (see below), to examine whether the different sources reveal the same trends and results.

\subsection{AMSTERDAM MARRIAGE BANNS}

In the Netherlands, parish marriage registers do not usually contain marriage ages, so unless the marriage date is combined with birth date, as in genealogical data, marriage ages are unknown. However, in a few, rather unique cases there are marriage ages to be found, though not necessarily in the actual marriage registers but rather, as in Amsterdam, in the declarations of the intention to get married (marriage banns). The Amsterdam marriage banns database is based on a sample from the registers of the marriage banns in the period 1605-1811, whereby every fifth year was sampled from. ${ }^{3}$ Couples with the intention to marry, had to register at church or town authorities at least three weeks before the official wedding ceremony took place and these banns were written down in the registers, including a large number of biographical variables that give us plenty of information on, amongst other things, the marriage age of and age difference between bride and groom (for first marriages only). Scholars have characterized seventeenth and eighteenth century Amsterdam as a migrant society (Kuijpers 2005): the economic growth and prosperity attracted young people from

$2 \quad$ One option to evaluate the accuracy of the overall marriage age estimates in the genealogical data was to compare them with estimates from the Historical Sample of the Netherlands (HSN) database (Mandemakers 2002 http://www.euppublishing.com/doi/abs/10.3366/hac.2002.14.1-2.87). The HSN database is based on the population registers, and certificates of birth, death and marriage, which were introduced nationally in the early 19th century for standardized recording of vital events. We are only able to compare the period $1850-99$, but we find a very close match in average marriage age, with male marriage age 0.8 years higher in the HSN database and female marriage age 0.6 years lower. Notably, not all marriages have been linked to births in the HSN data, hence the sample is about 17 times smaller, perhaps explaining the discrepancy of $0.6-0.8$ years with the genealogical data.

3 See the following link for more information on the project behind this dataset: http://www.collective-action.info/Ja-ik-wil/ 
other Dutch regions, but also from Germany and the Scandinavian countries in particular, who found work and settled in Amsterdam. Many of these migrants also found their marriage partner in their new place of residence (Somerseth et al. 2016). In certain periods, more than half of the marrying men and one third of all the women were born elsewhere. As each entry in the registers also contains the places of origin of bride and groom, this makes it possible to distinguish between people born in Amsterdam and migrants from other regions, and to compare the marriage patterns of the local population with those of migrants. The use of two data sets based on different sources makes it possible to check for potential biases. As mentioned above, genealogical data tends to show a bias toward larger and longer-lived families and married couples who had children, because people without a direct line of descent to future generations are less likely to be found by genealogists who primarily investigate their line of descent from the past. As will be discussed below, the differences in results between the two data sets especially regarding the female marriage ages suggest that also in our genealogical data set fertile couples are overrepresented. We come back to this point later, in the broader discussion about the relationship between migration, marriage ages and fertility levels.

\subsection{MARRIAGE AGE AND SPOUSAL AGE GAP}

To reach out to genealogists in the Netherlands, we worked in collaboration with a popular genealogy website (www.genealogieonline.nl). We contacted their members to ask whether they would allow their family trees to be used for scientific research purposes, on the condition that their work would remain confidential and only be published in an aggregated statistical form without further consent. The response was a contribution of 1,611 family tree files in the GEDCOM (GEnealogical Data COMmunication) format. The data underwent a thorough error screening process, in which files were excluded if they contained more than $0.5 \%$ of a number of potential error indicators relating to life events and family relations (see Appendix A). After filtering out those genealogical files with most errors, the data from 924 files remained in the database.

The events in genealogical data files are often associated with place names, but these often do not have geo-coordinates associated with them and are poorly standardised across files. As such, it was necessary to geocode the data (i.e. add geo-coordinates to the place names). This was done using a semi-automated procedure, whereby the place names in the genealogies were automatically matched (using a natural language search) to places in the GeoNames database, which is an open source geographical database that contains place names, alternative place names and geo-coordinates for places across much of the world. Human input was then used to identify which of the automated matches was the correct one. If none of the matches was correct, then the correct place, including geo-coordinates, was entered manually, or the place was marked as unknown. The geocoding was done blind to the type of event being geocoded, or to other events related to the individual, as this may have introduced a bias to human selection of the places.

Our analyses require information on the age in years of individuals at marriage, which is sometimes recorded in marriage registrations, or can be calculated when the date of birth and date of marriage is known. As we are working with historical data this information is not always available completely or very precisely, and sometimes we only know the year of birth or marriage. The Amsterdam marriage banns only report ages at marriage - no exact birth dates are recorded. In the genealogical data, we find that precise dates of birth, marriage or death are less common in older records (Gellatly 2015), which means that we are forced to inadvertently exclude older records by restricting our analyses to those records that have precise dates. As such, we base our models on crude age measurements using the year of birth and year of marriage to compute marriage ages and spousal age gaps.

To compare marriage ages in rural and urban places we use the marriage places of couples as coded in the genealogical data and base our definition of urban places on work by Eltjo Buringh, whereby if a place ever had more than 5,000 inhabitants during our study period we define it as urban. We conducted a comparison of different regions to detect regional variations that could be expected based on factors such as differences in inheritance systems, agricultural activities, level of commercialization and labour market opportunities (Kok, Mandemakers \& Mönkediek 2014). The regions are coded as 
follows: West $=$ Holland, Zeeland, Utrecht; East $=$ Overijssel, Gelderland, Drenthe; North $=$ Friesland, Groningen, South = Limburg, North Brabant.

\subsection{MIGRATION}

We look at migration in the context of marriage, defining migration as getting married in a different place than the one in which the person was born or baptized. To be able to compare marriage ages and spousal age gaps between local and migrating fractions of the populations, we split all marriages into the following four migration categories: 1) Non-migrating couple, 2) Only wife migrating, 3) Only husband migrating, and 4) Both partners migrating. All developments over time are based on 50-year marriage cohorts (e.g. marriage years 1650-1699, 1700-1749, etc.).

Beside this general definition of migrating and non-migrating individuals/couples, we also use actual migration distances. We define three different migration distance categories based on the migration distance between birth and marriage place of wife and husband, respectively. Category 1 comprises those who do not migrate (migration distance $=0 \mathrm{~km}$ ), category 2 those who migrate between 1-7 $\mathrm{km}$ (short distance migration to neighbouring communities) and category 3 those who migrate further away than $7 \mathrm{~km}$ (bird-eyes view) from their birth place, so beyond a daily reach of the parental place by foot. ${ }^{4}$ Using these different distance categories, we can make a distinction between those who lived within easy walking distance and those moving beyond a round-trip walk in a day to the parental home. In this way we can investigate if migration over a larger distance affected marriage ages or that the act of moving in itself already had an effect.

\subsection{ANALYSES}

We begin with descriptive statistics giving a general overview of age at first marriage for the Dutch genealogical data (The Netherlands and the Amsterdam sub-sample) and the Amsterdam marriage banns over time. We look at trends and possible sex-differences in marital timing in all data sets and regional variation within the Netherlands by reporting mean values for the variables of interest for 50-year marriage cohorts. Furthermore, we take a closer look with regional comparisons for different regions within the Netherlands and urban/rural places. To take the specific features of the different sources (genealogical data and marriage banns) into account, we explicitly compare results between the two data sets regarding the development in marriage ages.

In the second part of the paper we address the issue of migration and its possible effect on marriage age. First, we compare proportions of migrating individuals and differences in migration distances between men and women according to the three migration distance categories $(0 \mathrm{~km}, 1-7 \mathrm{~km},>-7$ $\mathrm{km}$ ). Second, we visualize differences in marriage ages between migration couple categories (migrating and non-migrating individuals/couples) to test if, and how migration affected marriage age. We also compare marriage ages of migrating people to both the mean marriage ages at the place of origin and the receiving community to find out to what extent different forms of migration affected individual marriage ages.

\section{$4 \quad$ RESULTS}

\subsection{OVERVIEW OF MARRIAGE AGES IN THE NETHERLANDS (1650-1899)}

In general, we find that average marriage age increased in the Netherlands over our study period (Figure 1). In 1650-99, the genealogical data tells us that average female marriage age was about 24 years and rose to about 25.7 years by 1850-99, with very little difference between Amsterdam (green dotted line) and all of the Netherlands (blue dotted line). However, the Amsterdam marriage banns tell us that average female marriage age was higher, at an average of 26 years in 1650, rising to 27.5 years by the late 1700 s to early 1800 s, when that data source ends. For men, the genealogical data

$4 \quad$ The classification is to some extent arbitrary as there are no harsh thresholds to define where social horizons as they differed per social group, town and countryside, type of activity etc. See for an overview of different thresholds and categories that are used to distinguish between short and longer distances: Hayhoe (2015) and Boulton (2009). 
indicates that the average marriage age was lower in Amsterdam than in the rest of the country. We see that marriage age rose from about 27.3 years in 1650-99 to 28.1 in 1850-99 for the whole of the country, with a peak of about 28.2 years in 1750-99. For Amsterdam, the average male marriage age was approximately 1 year lower from 1700 onwards. Comparing genealogical male ages with those from the marriage banns of Amsterdam we see a similar, but smaller difference as we already noted for women. Male marriage ages in the genealogies for marriages conducted in Amsterdam differ by around 0.8-1.2 years from those recorded in the marriage banns. Notably, also the difference between age at first marriage between men and women is much lower in marriage banns than in the genealogical data.

Figure 1 Average age at first marriage for all of the Netherlands, based on genealogical data and marriage banns data (Appendix B, Table 1, 2 \& 3).

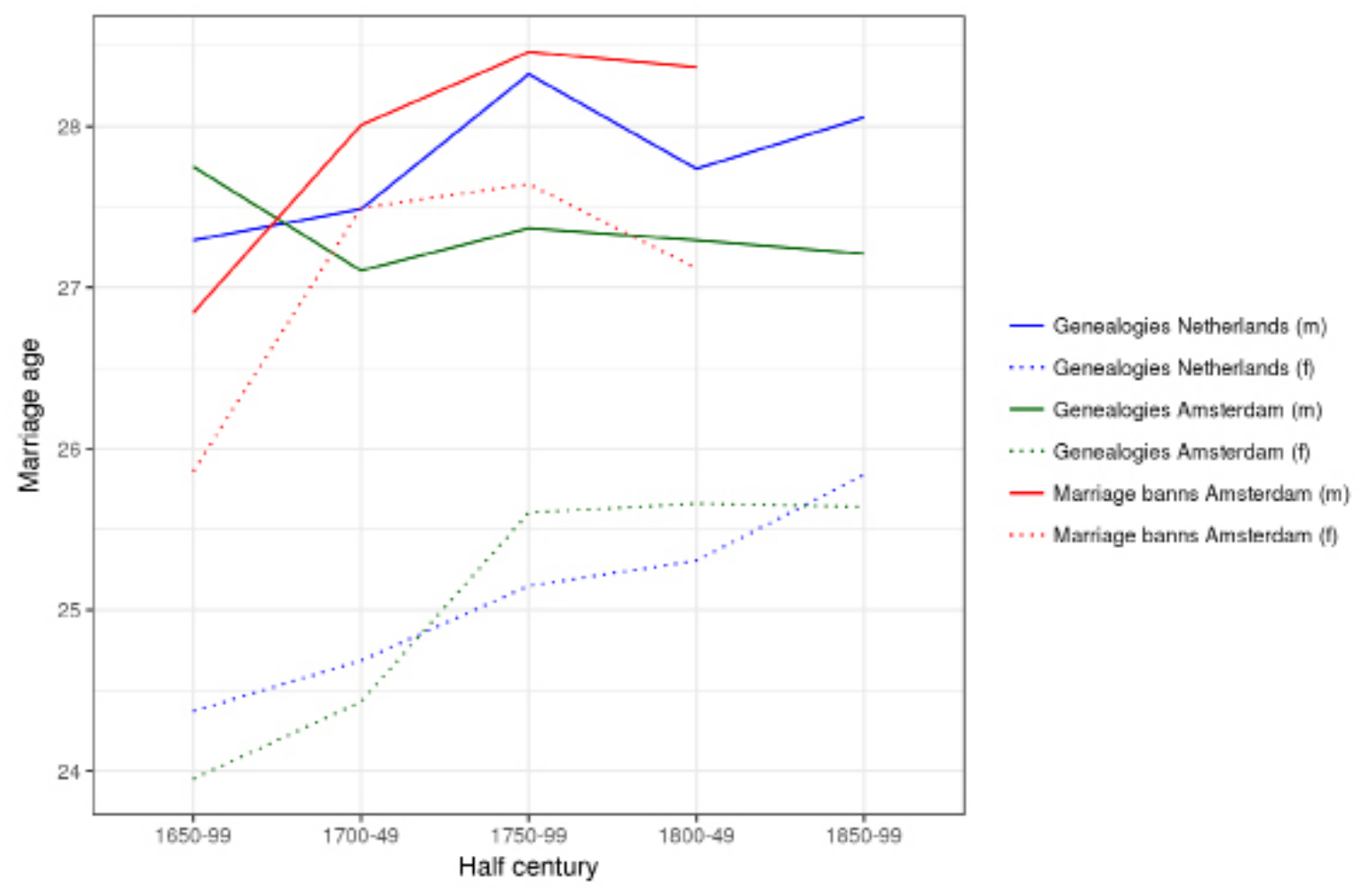

Analysis of the difference in age at first marriage between marriages conducted in the North, South, East or West (Figure 2) shows that the highest marriage age for women throughout the study period is in the south. For men, until the beginning of the nineteenth century, it was those living in the Eastern part of the country that had the highest marriage ages. Their position was taken over by Southern males marrying between 29 and 30 years old. In the West, men consistently show a lower average marriage age, of around 27 years. In all regions, male marriage ages gradually increased until the end of the eighteenth century, while slightly decreasing in the nineteenth century (with exception of the South). In contrast to this decrease in male marriage age in the first half of the nineteenth century, female marriage ages show an almost continuous increase from 1650 until 1900, with the largest rise in the nineteenth-century South. The only exception is the small decrease in the Western part of the country in the beginning of the nineteenth century. Furthermore, men and women in the East consistently married later over the study period than men and women from the West and the North.

Analysis of the difference between urban and rural marriage locations (Figure 3 ) shows that the average age at first marriage was higher for rural males, from at least 1750-99 onwards, by just under 1 year. There was not such a large difference for women, but we see an opposite trend to males, in which urban women are starting to marry later than rural women by 1750-99, at the point when urban men are starting to marry earlier than rural men. By the mid-1 $8^{\text {th }}$ century, therefore, we see a considerable narrowing of the difference in age at first marriage between the sexes. Notably, this does not correspond exactly to the spousal age gap (husband's age - wife's age), though we can be fairly certain that this was also declining in urban relative to rural areas, mainly as a consequence of higher marriage ages for women. 
Figure 2 Average age at first marriage of men and women in different regions of the Netherlands, based on genealogical data (Appendix B, Table 4).

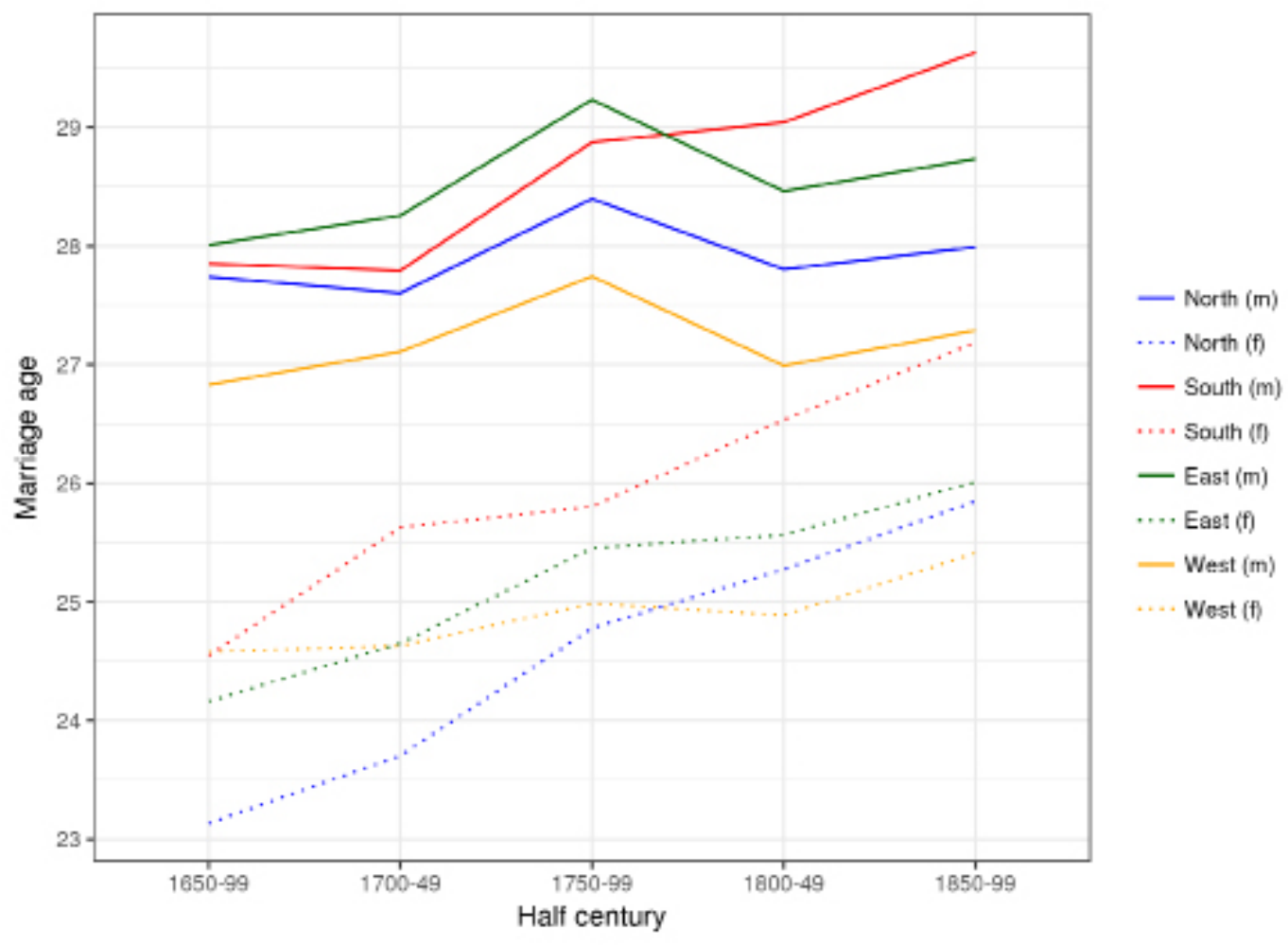

Figure 3 Average age at first marriage for urban and rural marriages for all of the Netherlands; genealogical data (Appendix 2, Table 5).

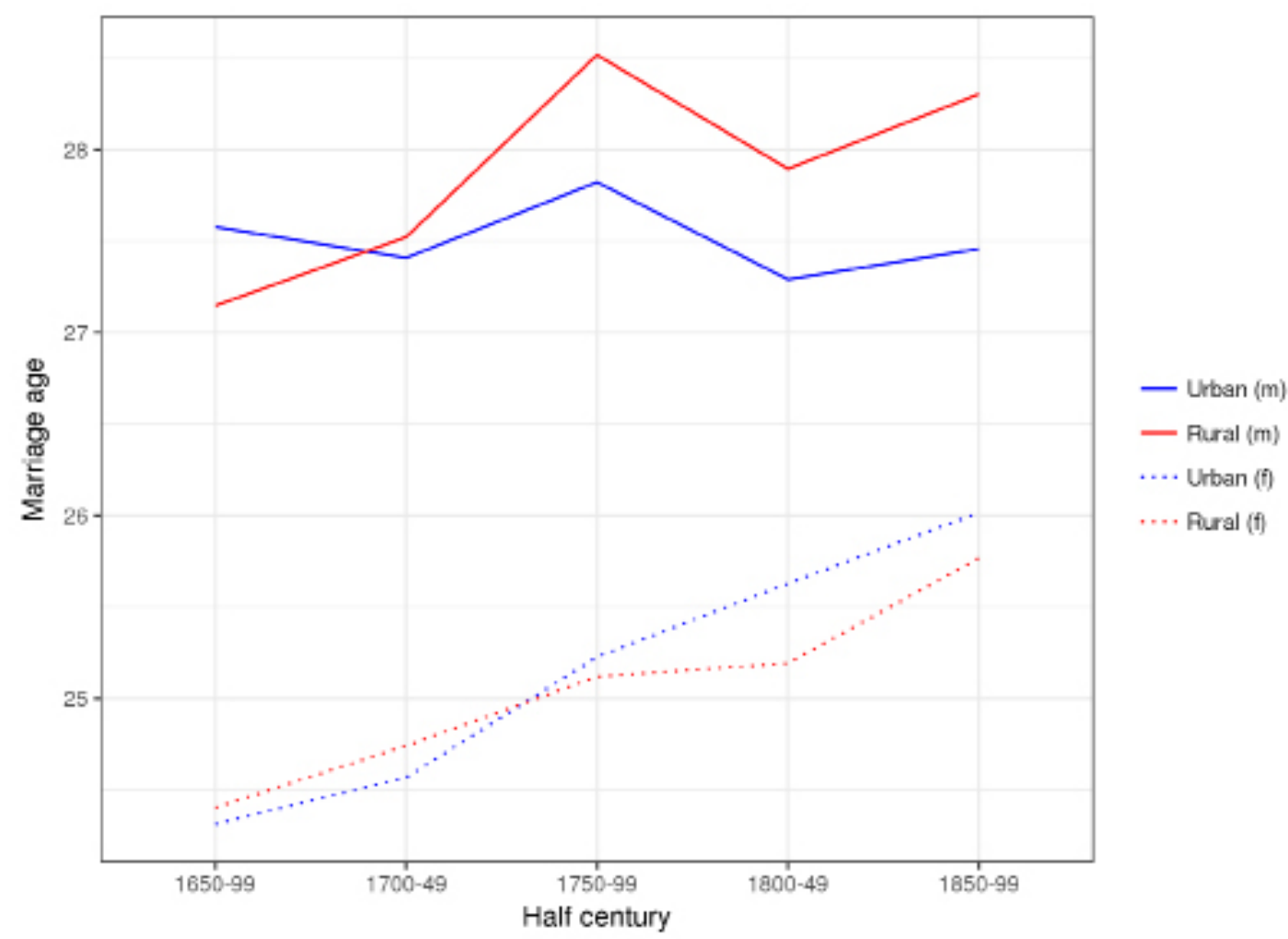




\subsection{MARRIAGE AGES IN AMSTERDAM (1650-1810)}

The record of the place of origin in the marriage banns of Amsterdam allows us to distinguish between those individuals who were born in the city and those who had migrated to the city, and we see a very clear difference between the marriages ages of those who were local to Amsterdam and those who migrated to the city (Figure 4). Immigrants were marrying considerably later than locals, by between 2 and 3 years. This difference applies to both men and women, and we see that the difference in marriage age between locals and migrants is much greater than the difference between men or women in either category.

In the overview, we already saw that there is a distinct difference in age at first marriage between the marriage banns of Amsterdam and the genealogies. To investigate this further, we looked at the difference in age at first marriage for local born individuals only, in both data sets (Figure 5). Again, we see that marriage ages are higher in the marriage banns than in the genealogies, but also that the difference is higher for women. We will come back to this point in the discussion.

Figure $4 \quad$ Average age at first marriage of locals and migrants in Amsterdam, based on marriage banns (Appendix B, Table 6).

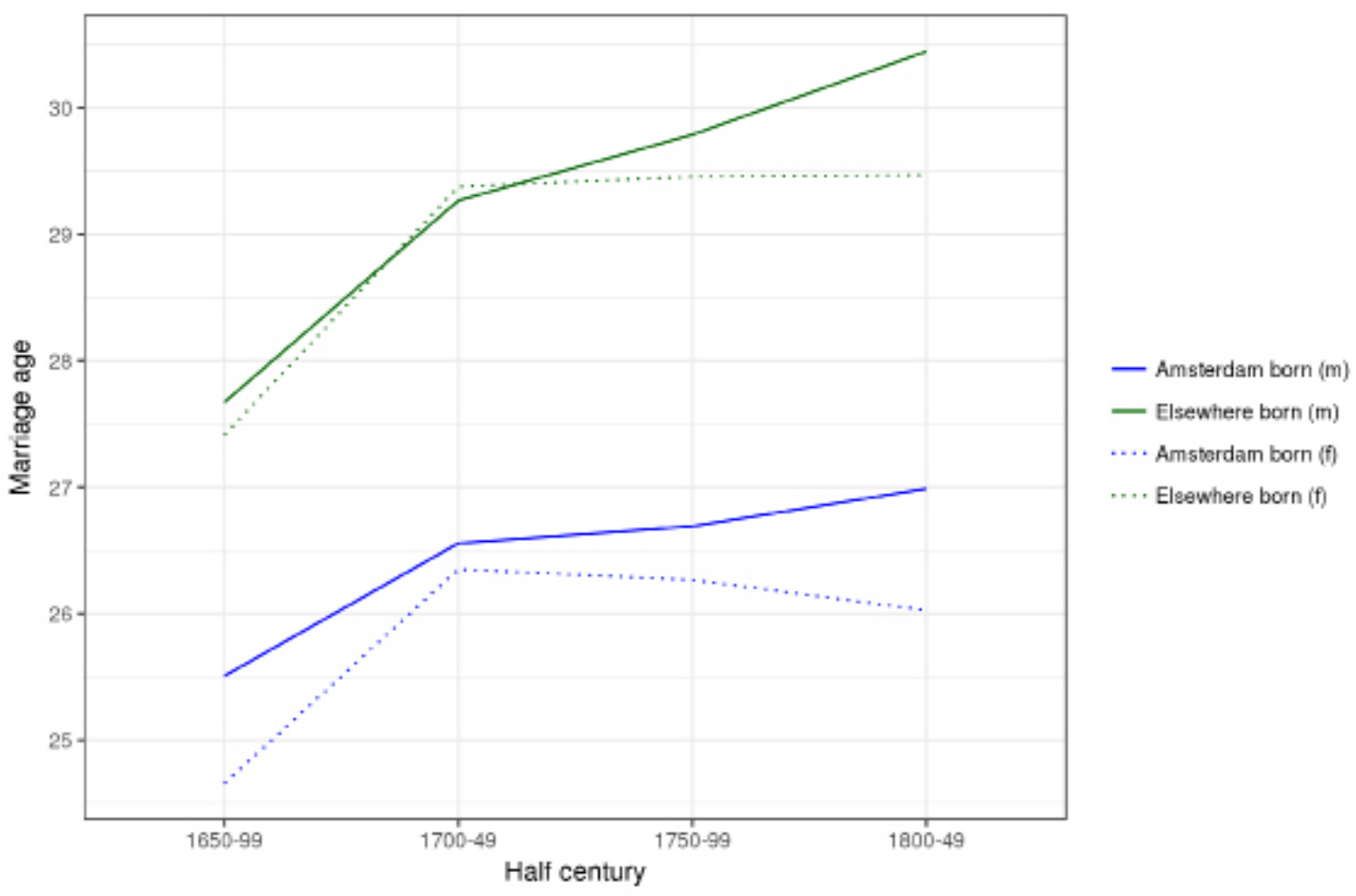


Figure 5 Age at first marriage of those born and marrying in Amsterdam, compared between marriage banns and genealogies (Appendix 2, Table 6 \& 7 ).

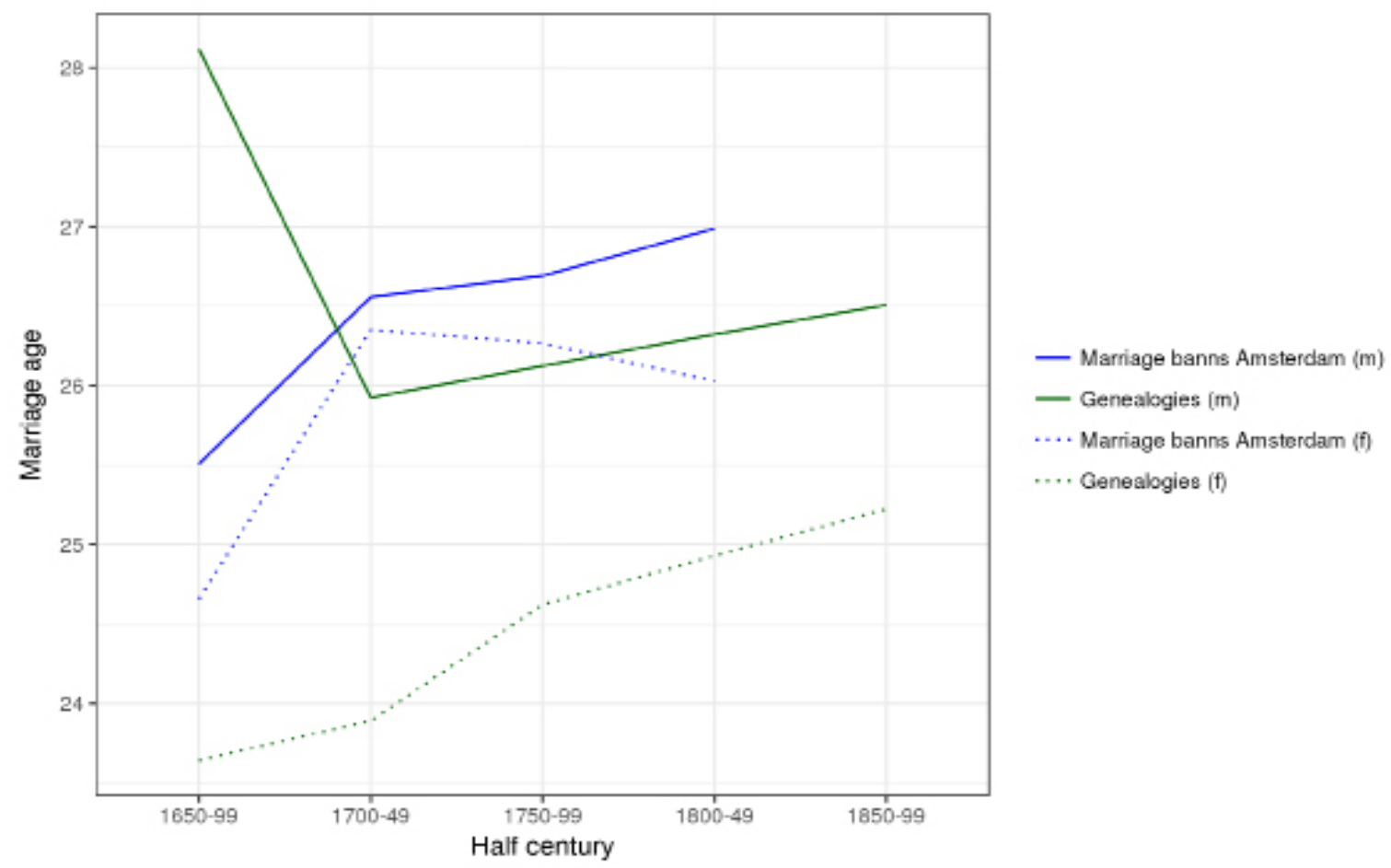

\subsection{MARRIAGE AGE AND MIGRATION IN THE NETHERLANDS (1650-1899)}

We are able to make several observations about migration. A clear pattern is that men were in all cases (very similar results for all data sets) more likely to have migrated before their first marriage than women (Table 1), although the difference between the two sexes is rather small.

Table $1 \quad$ The proportion of males and females migrating between their birth place and their first marriage, for marriages and births in the Netherlands, based on genealogies.

\begin{tabular}{|l|c|c|c|c|c|}
\hline & 1650 & 1700 & 1750 & 1800 & 1850 \\
\hline Males & & & & & \\
\hline $0 \mathrm{~km}$ & 63.7 & 64.6 & 62.1 & 55.1 & 53.2 \\
\hline $1-7 \mathrm{~km}$ & 14.2 & 14.8 & 15.3 & 17.9 & 16.1 \\
\hline$>7 \mathrm{~km}$ & 22.1 & 20.6 & 22.7 & 27.0 & 30.7 \\
\hline & & & & & \\
\hline Females & & & & & \\
\hline $0 \mathrm{~km}$ & 69.6 & 69.5 & 65.6 & 59.1 & 61.5 \\
\hline $1-7 \mathrm{~km}$ & 13.6 & 13.9 & 15.0 & 17.0 & 14.2 \\
\hline$>7 \mathrm{~km}$ & 16.7 & 16.6 & 19.4 & 23.9 & 24.3 \\
\hline
\end{tabular}

Another clear observation about migration is that those individuals who migrated between birth and marriage tended to marry later. In Figure 6, we compare those who stayed or migrated from the East to the West or vice versa. We find that for males and females who were born in the West (where we see the lowest marriages ages) and migrated to the East, marriage age raised by over 1.5 years. For those who migrated from the East to the West, changes in marriage age compared to their place of origin were smaller, at least for men. In the middle of the eighteenth century migrating men were even marrying earlier than stayers in the east. For women migrating to the West the differences are even more pronounced with marriage ages increasing with 2-2.5 years. This clearly reflects the 
disadvantaged position of migrating women in the marriage market in Western towns. The distorted sex ratios, in eighteenth-century towns in Holland, could even rise as high as 140 women per 100 men (Schmidt \& Van der Heijden 2016). This made it very difficult for migrating women to find a marriage partner (see also Puschmann et al. 2016).

We did the same comparison for rural-urban migrants because, as can be seen in Figure 3, there is an apparent difference between urban and rural age at first marriage for men. We break down the urban and rural marriages by those individuals who were born in urban or rural locations and divided them into 'stayers' (= same place of birth and marriage) and 'leavers' (birth place $\neq$ marriage place). For men, with the exception of the $17^{\text {th }}$ century, rural stayers had a higher marriage age than urban stayers, although for women, there was little difference (Figure 7a). In terms of those who migrated from one place to another at some point between birth and marriage, ages of the stayers were always lower. The only exception are seventeenth century female migrants who moved from one urban environment to another.

Figure 6 Average age at first marriage of those born and marrying in the East or West, and those migrating between the two regions; genealogical data (Appendix 2, Table 3).

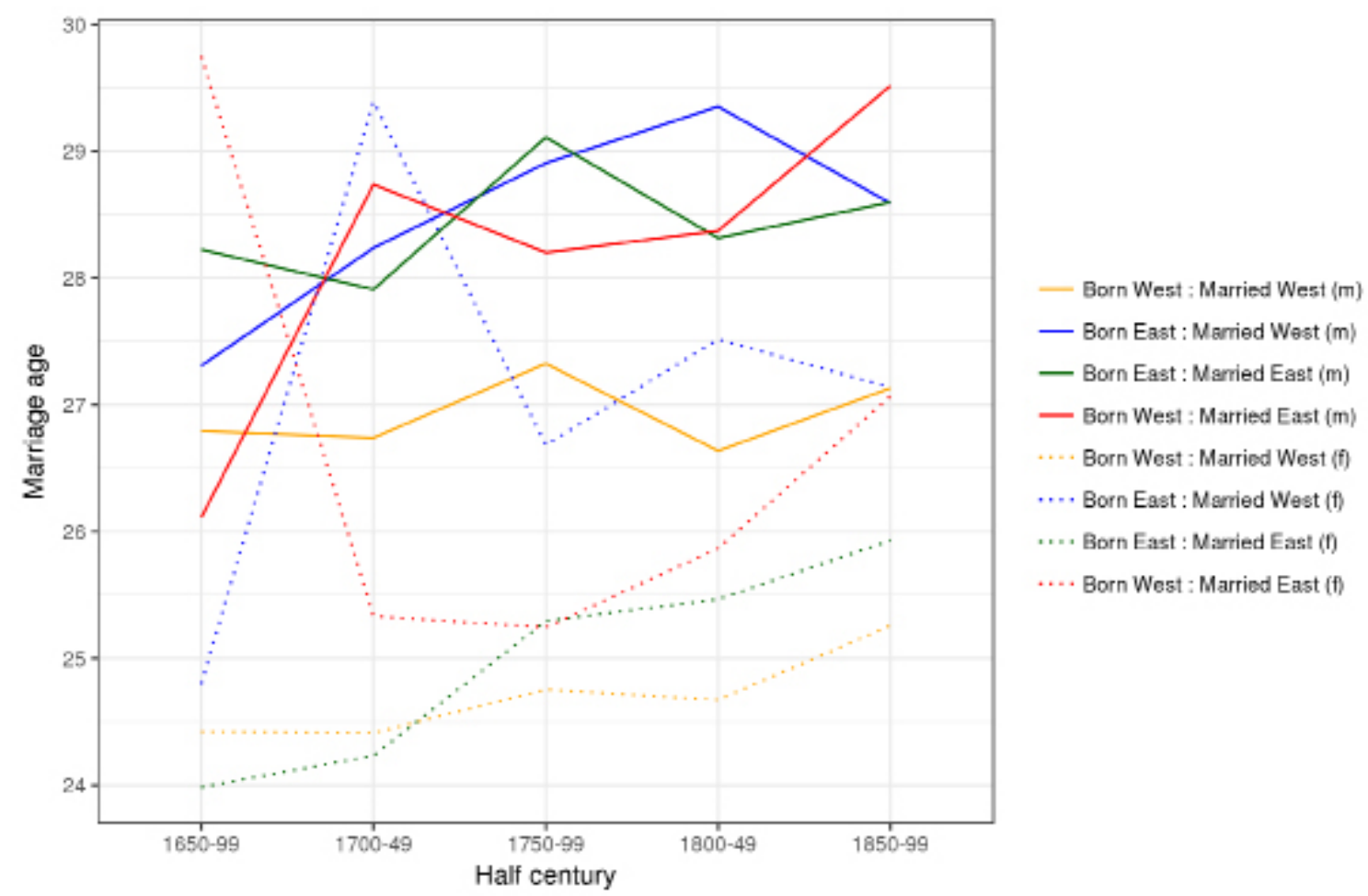

It also becomes clear that the impact on marital timing depended on the direction of migration. The general picture for male migrants is that until the eighteenth century urban to rural migrants married latest, whilst rural to rural and rural to urban migrants married earliest. However, the difference in male marriage age between those individuals moving from a rural to an urban place and the men who stayed in the same rural place was much smaller than the difference between those men who moved from an urban to a rural location and the urban stayers. As such, the impact on marital timing was smaller for migrants who moved from a rural to an urban location than for those who migrated in the opposite direction.

In addition, Figure $7 \mathrm{~b}$ shows that in 1650-99 and 1700-49, there were greater differences between the marriage ages of migrating individuals, depending on the direction of migration. By the late $18^{\text {th }}$ and $19^{\text {th }}$ century these differences had more or less disappeared, particularly for men, though their marriage age remains slightly higher than that of non-migrating individuals. For women, we see a dramatic increase in average marriage age by nearly 5 years over the study period for those who were born in an urban place and married in another urban location. Women who migrated from an urban to a rural location showed the highest age at first marriage until 1800. 
To address the question of whether the act of migration in itself was the driver of higher marriage age, we looked at the difference between those who married in their native town ('stayers') and those who married in another town or city ('leavers'), also taking into account whether their spouse was a 'stayer' or a 'leaver' (Figure 8). It is very clear that marriage ages are highest for marriages in which both partners were leavers, followed by those where one partner was a stayer and the other a leaver. As we saw in Figure 4 for Amsterdam and Figure 7 a for the whole country, the local-born individuals are those who have the lowest marriage age.

Not only do we find that the act of moving away from the place of birth results in a higher age at first marriage, we also find that there is a direct relationship between the distance that people migrated and the age at first marriage. This is clearly seen in Figure 9, where we see for both sexes that those who married latest were those who had migrated the longest distance.

Figure 7a Age at first marriage of those born and marrying in the same urban or rural place (Appendix B, Table 9).

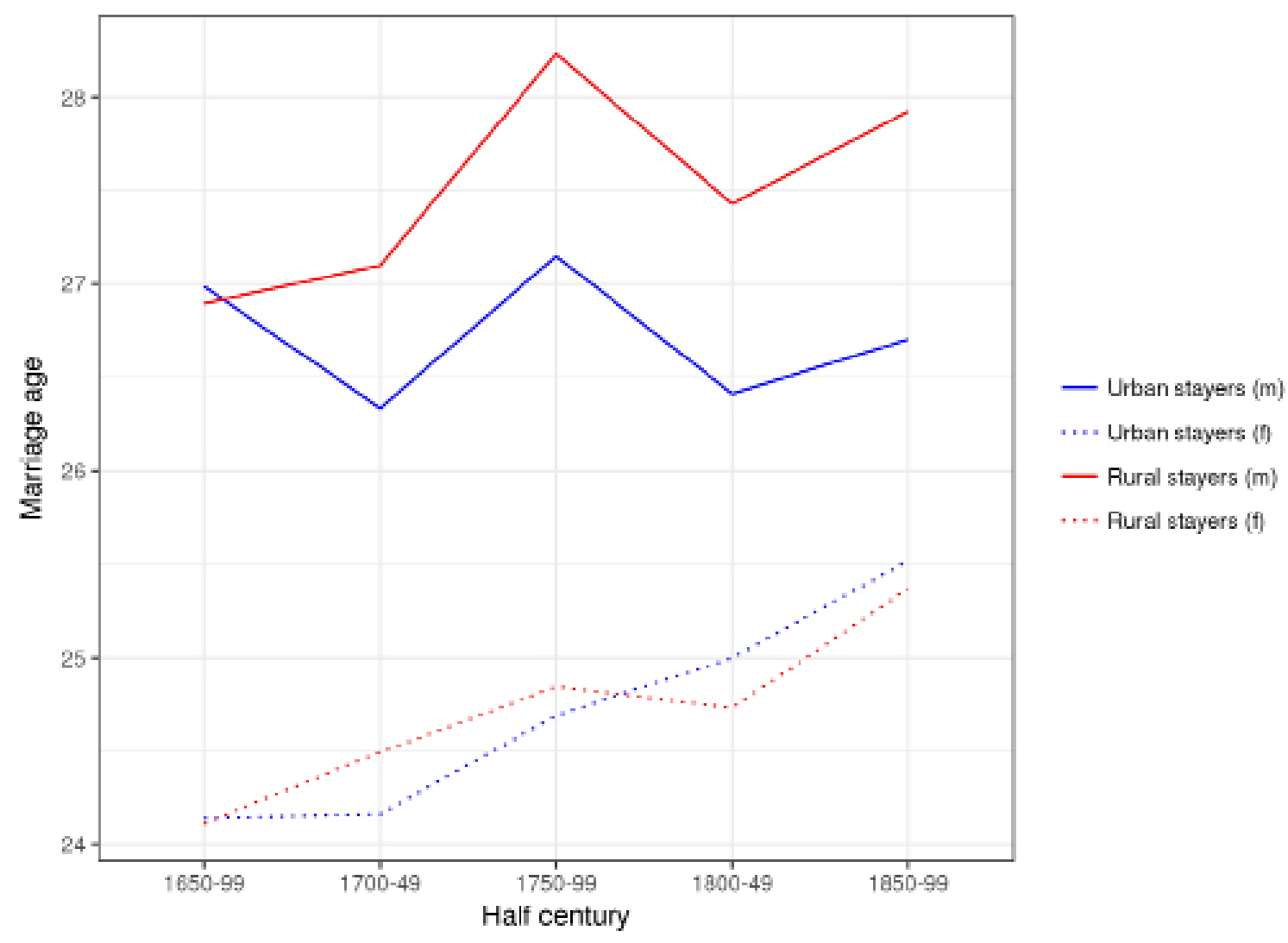


Figure $7 b \quad$ Age at first marriage of those marrying in another urban or rural place than their place of birth across all of the Netherlands (Appendix B, Table 10).

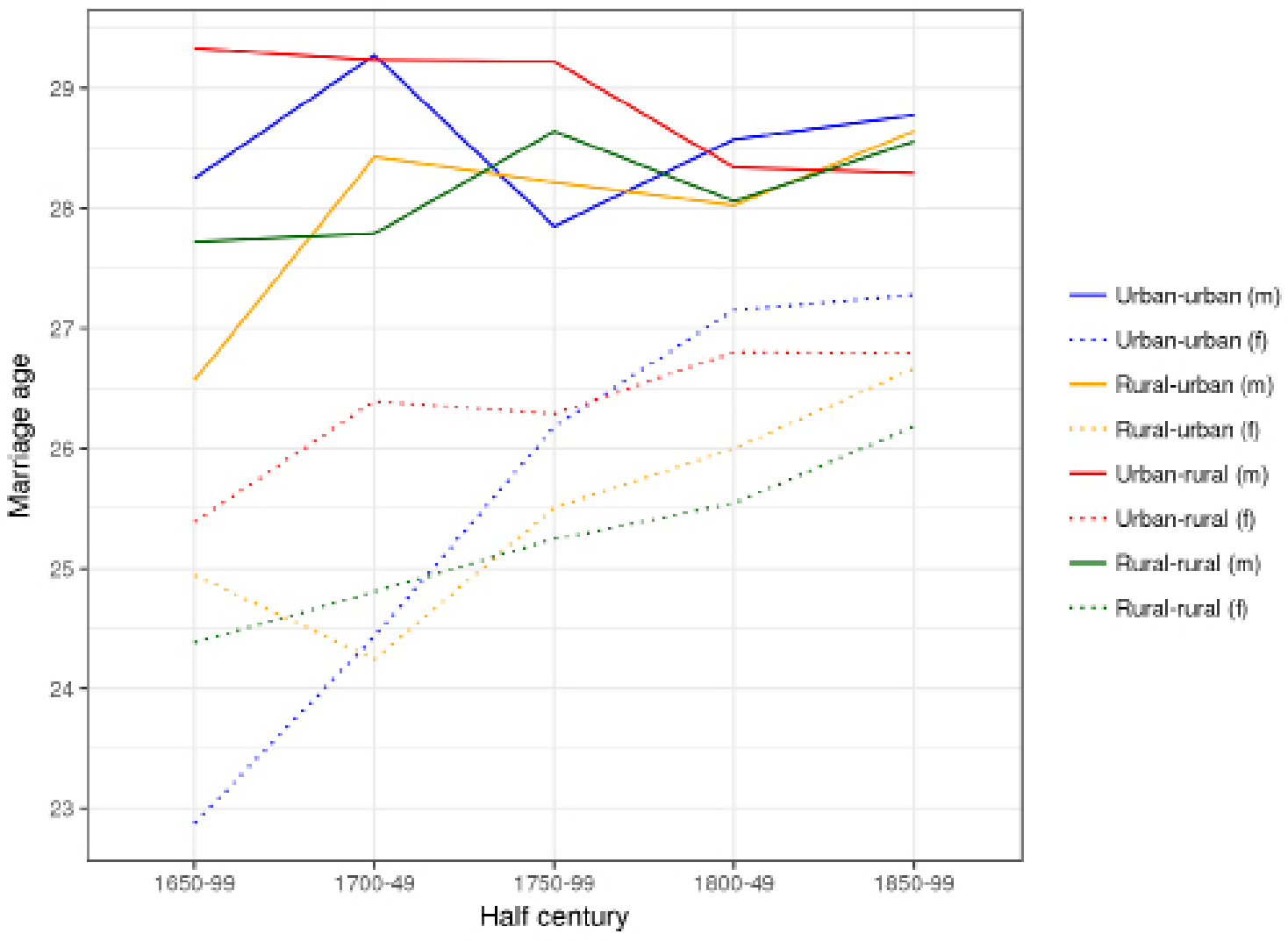

Figure $8 \quad$ Average age at first marriage of those who stayed where they were born, compared to those who left their birth place at some point in time before marriage, across all regions, also taking into account the migration of the spouse. The asterisk denotes that this was the first marriage for this spouse only (Appendix B, Table 11).

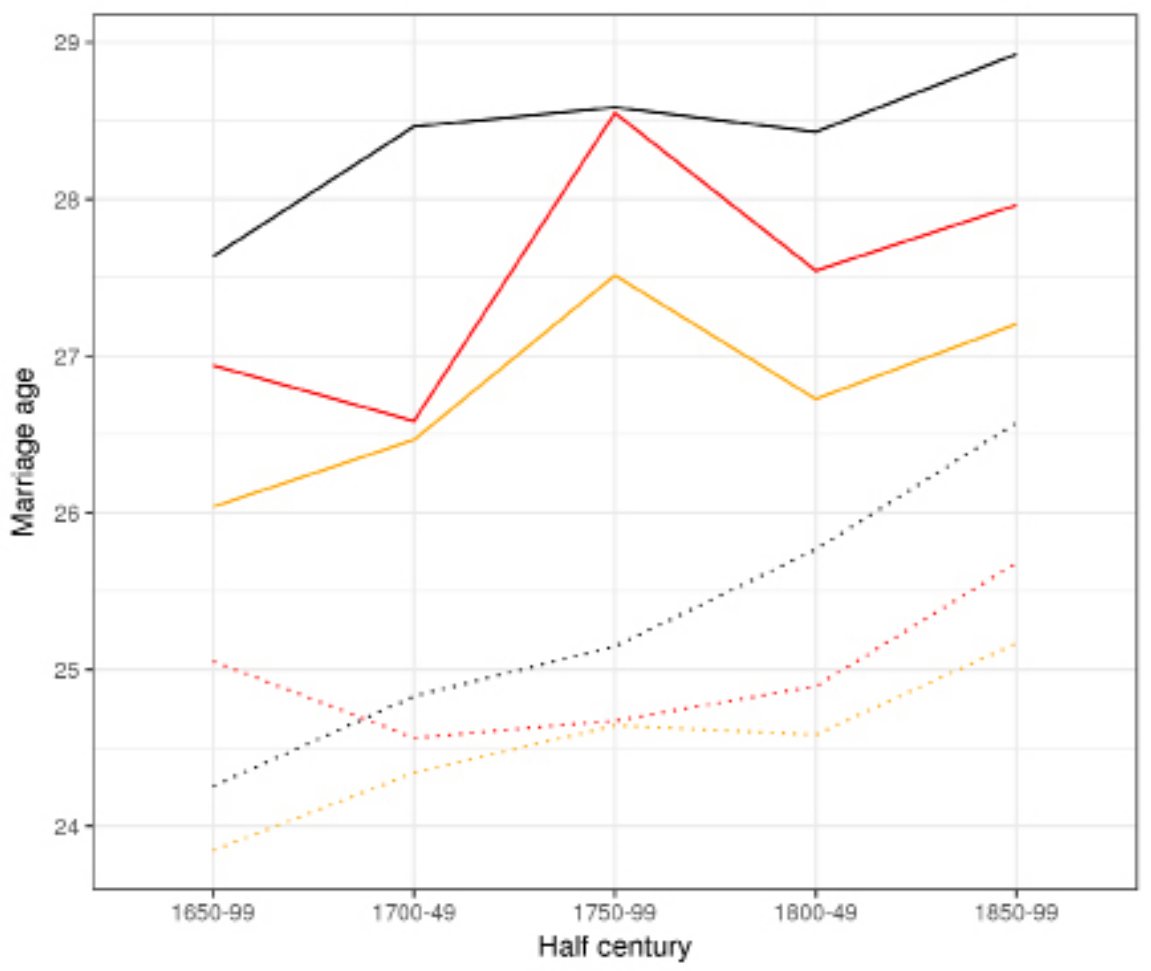


Figure 9 Average age at first marriage according to the distance of migration between birth and marriage location; genealogical data (Appendix B, Table 12).

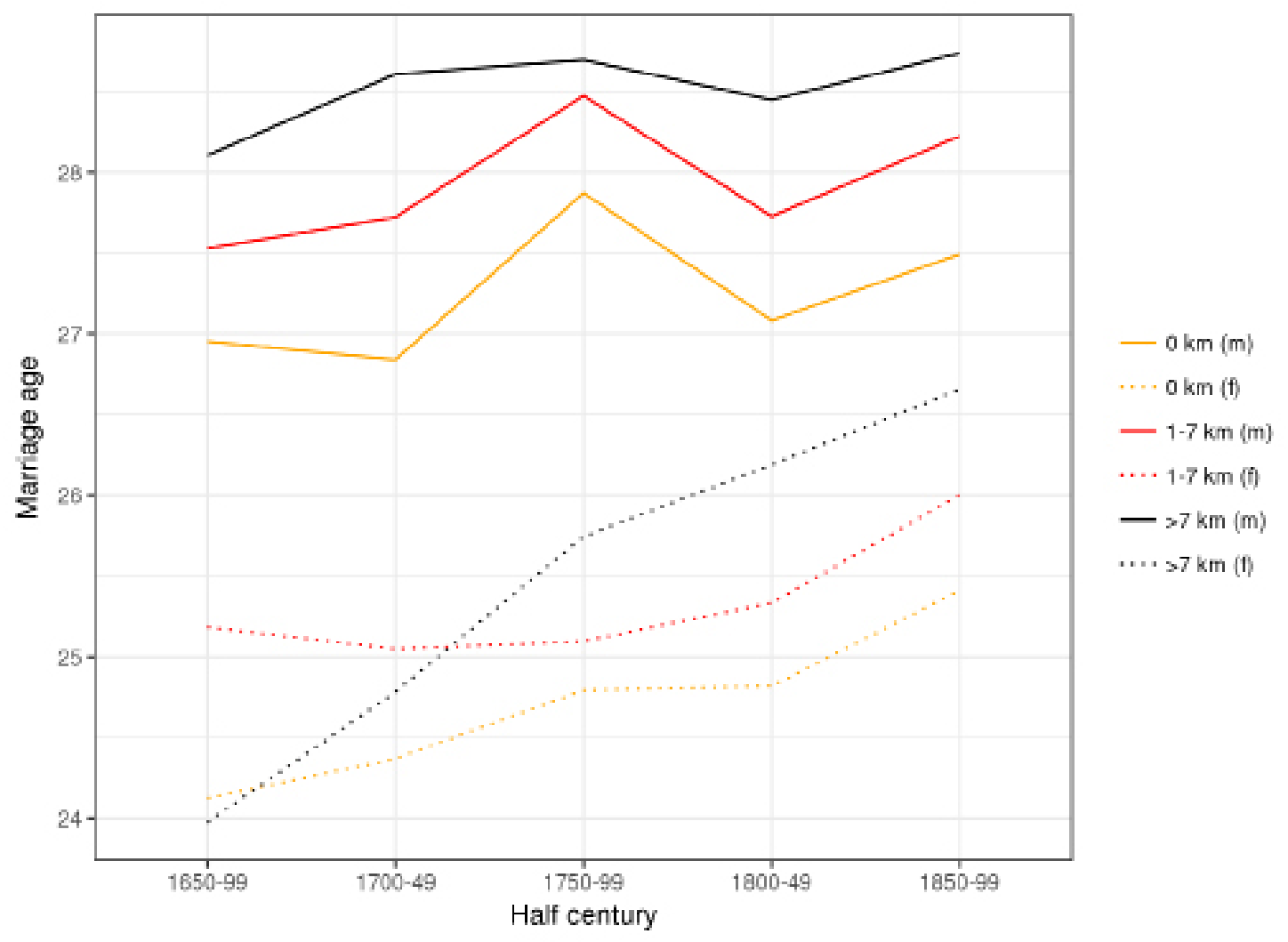

In this study, we observe a steady increase in marriage age, particularly for women, in the Netherlands between 1650 and 1900. In the analysis of the regional as well as urban and rural variations, we find pronounced differences between the North, South, East and West and between urban and rural locations. Both men and women married at a higher age in rural regions as well as in the Eastern and Southern parts of the country. These regional differences in fact suggest how, within a certain marriage system, regional conditions could influence actual outcomes of marital timing. As has also been argued by Carmichael et al (2015) within EMP-regions, marriage ages responded to economic developments and were lower in the more prosperous and populous than in the stagnating regions. In the Netherlands, economic conditions in the coastal and more urbanized and commercialized regions of provinces such as Holland and Zeeland were in general more favourable than in the inland regions. Therefore, in the coastal regions it was easier to earn the necessary income by participation in the labour market to start and maintain a household thus the economic conditions facilitated earlier marriage. In the more agricultural regions in the East and South of the country, on the other hand, men had to postpone marriage until they inherited the land necessary to maintain their own household (Bras \& Van Tilburg 2007).

The difference in age at first marriage between urban and rural locations was most significant for men. From the period 1750-99 onwards, men in urban centres were getting married about 1 year earlier than their rural counterparts. This is in contrast to women who were starting to marry later than their rural counterparts around this time. The lower male age and higher female age at first marriage in an urban context may have different causes. For men, on the one hand, the opportunity for employment in urban locations may have provided the means to start a family earlier. On the other hand, the chances to find a suitable marital partner may have been higher for men in urban contexts as in general sex-ratios were more beneficial for men in urban communities. Since the late middle ages women 
were often overrepresented in urban populations (Van Bavel 2010; Schmidt \& Van der Heijden 2016). Hence, the female-biased sex-ratios in early modern towns (Schmidt \& Van der Heijden 2016) made urban environments much more beneficial for men who wanted to get married (Engelen \& Kok 2003). This contrasts strongly with the position of women and especially those who migrated. They had to compete with local women in the marriage market, whose marriage age also increased over time.

In terms of migration, we found major differences between 'leavers' and 'stayers'. Unfortunately, our sources do not provide information about the timing of migration. However, our rather crude migration indicator showed that migration had an important effect on marital timing with higher marriage ages for both men and women who did not marry in their place of birth. Furthermore, people who moved from a region with relatively high marriage ages to an area with favourable economic conditions married later compared to both the stayers in their place of origin and the receiving community. Therefore, we can conclude that in the early modern Netherlands the potential economic benefits of migration, which could facilitate the collection of necessary savings to start one's own household and thereby making an earlier marriage possible, did not outweigh the difficulties related to moving to a new environment (see also: Puschmann 2016). The only exception is the second half of the eighteenth century, when marriage ages of male migrants moving from a rural to an urban place were the same as their male peers staying in the rural community. For men, marriage conditions in cities were apparently better than in the countryside in this period.

The direction of migration, however, influenced the impact of migration on an individual level. The results from the comparisons of mean marriage ages for the different regions (West, North, South and East; urban - rural) showed that marriage age was lowest in the West and moving from the East to the West of the Netherlands did not cause men to marry much later than those staying in their Eastern place of birth. In the middle of the eighteenth century, men migrating to the West were even marrying earlier than stayers in the East.

There was a higher percentage of marriages in which the husband was the migrating partner whereas the wife was born in the same town as the place of marriage, as compared to the percentage of marriages where this was the other way around. This finding might have been expected given that the employment opportunities for men were more likely to involve travel, e.g. various transportation services, military postings or civil construction projects. However, due to the crude migration indicator we are using here, we cannot tell at which age individuals migrated, e.g. if migration was linked to marriage prospects at the local marriage market or due to migration of the natal family when the individual was still a child. In the Netherlands, there was a tradition to get married in the home town or village of the bride. Therefore, we might overestimate male migration rates and underestimate female migration rates to some extent.

Another important finding is the difference in marriage age for women between the Dutch genealogical data for Amsterdam and the data which is based on the marriage banns of Amsterdam. It is somewhat surprising that the age at first marriage is higher in the marriage banns than in the genealogical data, particularly for women. For the marriage banns, we know when a marriage is a first marriage, because individuals do not have to report their age for a second (additional) marriage and their marital status (e.g. widowed) was mentioned as well. In the case of the genealogical data, we only know whether the individual has previously been married if we have a date for another marriage in which they appeared. Therefore, we excluded all marriages where we could not tell whether another marriage occurred before or after. It would seem, therefore, that the disparity between the two datasets cannot be explained by inadvertent inclusion of second marriages. It also seems unlikely that it can be explained by the appearance of more migrants in the Amsterdam marriage banns, as we compared those who were born in Amsterdam only.

The likely explanation for higher marriage ages of women in the Amsterdam marriage banns is that this data also includes marriages which were not ultimately fertile, because the data selection comes from a cross-section of all marriages conducted in the city of Amsterdam. In contrast to that, the marriages that we see in the genealogies are much more likely to have been fertile marriages, which not only produced children, but produced children who themselves had children, and ultimately some posterity that then appears in a $21^{\text {st }}$ century Dutch genealogy. The difference illustrates an important constraint on marriage age at the time. Infant mortality was high, so it was important for a woman to marry on time to ensure reproductive success. It is perhaps a sign of the improvements in child survival that occurred in the mid-18th century (Anderson 1988), which explains why the disparity in marriage 
age between the genealogical data and marriage banns declines between 1700-49 and 1800-49. It may have been possible for women to marry later by the late-1700s to early 1800 s and still leave surviving offspring.

As a test of whether the disparity in marriage ages between the Amsterdam marriage banns and the genealogical data could be caused by infertile marriages for older couples, we compared mean ages at first marriage in fertile and infertile marriages in the Dutch genealogical data, including only couples where the date of birth and death for husband and wife were known, and no birth or death dates were estimated (Table 2, Figure 10). We find that for both sexes, but women in particular, age at first marriage is lower in fertile marriages than in infertile marriages. This trend is also consistent over time, which is indicative of a well-understood biological effect, i.e. reduced fertility for older women (Bongaarts 2015). This test does not measure the overall fertility of women and men who marry later, but there is no doubt that women who marry later have a reduced window of fertility, so we would expect to see a negative correlation between marriage age and fertility, particularly in data that predates the demographic transition.

Table 2 Percentage of couples with and without children; Dutch genealogical data, all marriages

\begin{tabular}{|c|c|c|c|}
\hline Marriage Half Century & $\mathbf{n}$ & Childless (\%) & Children (\%) \\
\hline $1650-99$ & 893 & 15.7 & 84.3 \\
\hline $1700-49$ & 2,316 & 16.9 & 83.1 \\
\hline $1750-99$ & 9,134 & 15.7 & 84.3 \\
\hline $1800-49$ & 47,553 & 25.9 & 74.1 \\
\hline $1850-99$ & 89,989 & 30.9 & 69.1 \\
\hline
\end{tabular}

Figure 10 Marriage ages of husbands and wives in fertile and infertile marriages; Dutch genealogical data, first marriages only

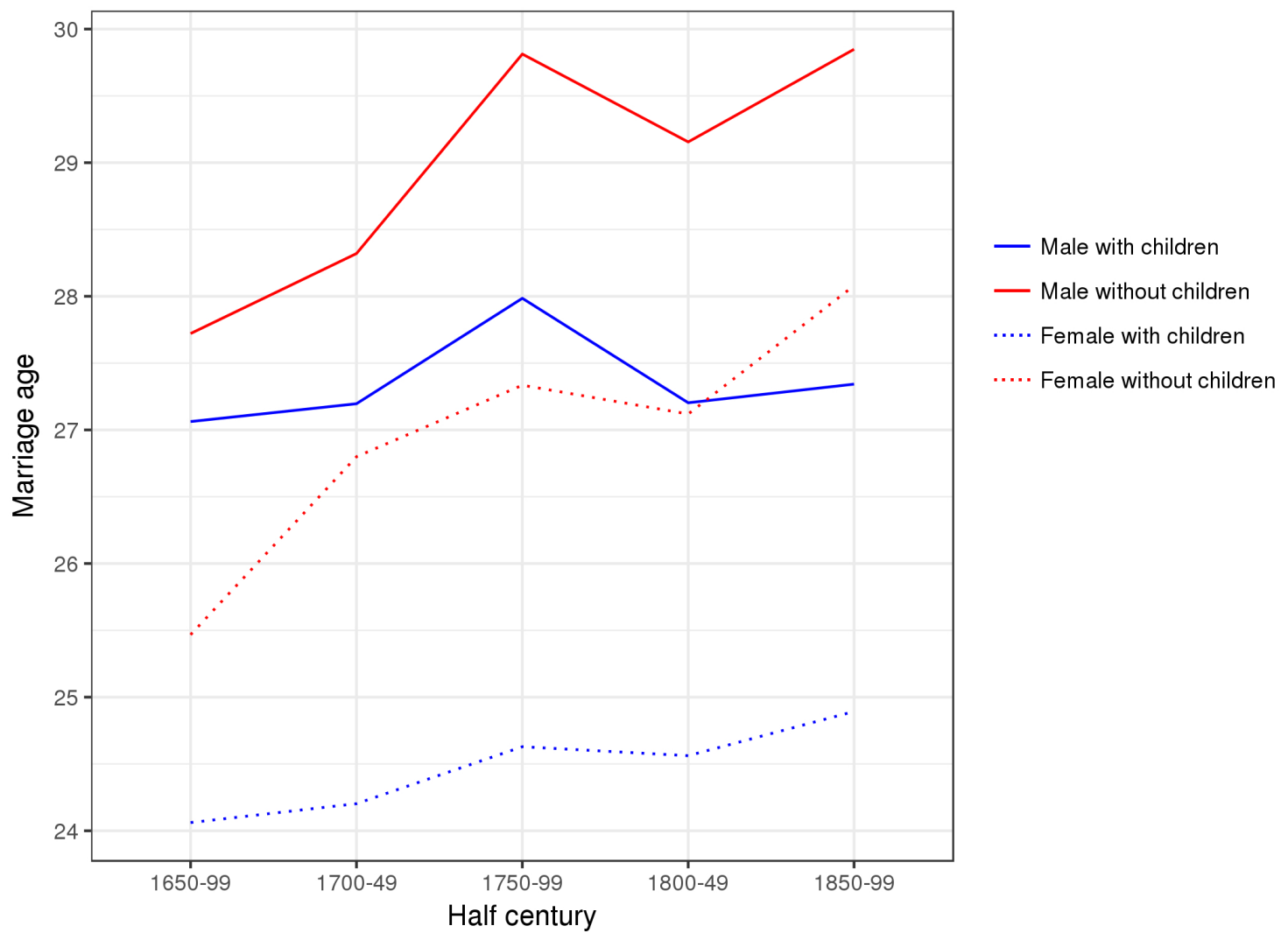


What does the difference in marriage age between those who migrate or not tell us about the historical development of marriage patterns? It suggests that where there is greater mobility of young people - which occurs whenever there are large urban centres, such as Amsterdam, that draw in labour from surrounding regions - we can expect average marriage ages to increase. Moreover, when migration is not only limited to men, but when both partners are migrating away from their birth places and getting married in other places, then we can expect an even greater increase in marriage age. It is clear, from a biological perspective, that later marriages are on average going to be less fertile. Therefore, we postulate a more direct link than has been suggested before, between increasing mobility of individuals in and around the $18^{\text {th }}$ century and a lowering of fertility levels in Western Europe already before the nineteenth century demographic transition (Mateos-Planas 2002; van Poppel et al. 2012). The mechanism behind these lower fertility levels differs from that in the next century, as it appears to have been driven by migration. We find across the Dutch data sets that marriages where both spouses marry in the place where they were born had the lowest marriage ages, whereas when both spouses were marrying in a new town, marriage ages for both spouses were higher. This suggests that migration and increasing mobility may have been an important driver of the demographic shift toward higher marriage ages and lower fertility in Europe between the $17^{\text {th }}$ and $19^{\text {th }}$ centuries.

\section{ACKNOWLEDGEMENTS}

We thank Eltjo Buringh for the dataset with information on urban places with $>5,000$ inhabitants in the Netherlands post-1600 period.

\section{REFERENCES}

Anderson, M. (1988). Population Change in North Western Europe, 1750-1850 (Studies in Economic \& Social History). Basingstoke: Palgrave Macmillan.

Bavel, J. van (2010). Choice of study discipline and the postponement of motherhood in Europe. The impact of expected earnings, gender composition and family attitudes. Demography, 47(2), 439458.

DOI: $10.1353 / \mathrm{dem} \cdot 0.0108$

Bongaarts, J. (2015). Modeling the fertility impact of the proximate determinants: Time for a tune-up. Demographic Research, 33, 535-560.

DOI: 10.4054/DemRes.2015.33.19

Boulton, J. (2009). Neighbourhood and Society. A London Suburb in the Seventeenth Century. Cambridge: Cambridge University Press.

Bras, H. \& van Tilburg, Th. (2007). Kinship and social networks. A regional analysis of sibling relations in twentieth-century Netherlands. Journal of Family History, 32(3), 296-322.

DOI: $10.1177 / 0363199007300244$

Carmichael, S. G., De Moor, T. \& van Zanden, J.L. (2011). “When the heart is baked, don't try to knead it" - Marriage age and spousal age gap as a measure of female "agency" (CGEH Working paper No. 19).

Carmichael, S. G., de Pleijt, A. \& van Zanden, J.L. (2015). Reply to Tracy Dennison and Sheilagh Ogilvie: The European Marriage pattern and the Little Divergence (CGEH Working Paper No. 70).

Charbonneau, H., Desjardin, B., Légaré, J. \& Denis, H. (2000). The population of the St. Lawrence Valley, 1608-1760. In R. Haines \& R. Steckel (Eds.), A Population History of North America (pp. 99-142). Cambridge: Cambridge University Press.

Cilliers, J. (2013). Cape Colony Marriage in Perspective. Stellenbosch: Stellenbosch University. 
Dennison T. \& Ogilvie, S. (2014). Does the European Marriage Pattern Explain Economic Growth? The Journal of Economic History, 74(3). 651-693.

DOI: $10.1017 /$ S0022050714000564

De Moor, T., \& van Zanden, J. L. (2010). Girl power: the European marriage pattern and labour markets in the North Sea region in the late medieval and early modern period. The Economic History Review, 63,1, 1-33.

DOI:10.1111/j.1468-0289.2009.00483.x.

Flinn, Michael W. (1981). The European demographic system, 1500-1820. Brighton: The Harvester Press.

Engelen, T. \& Kok, J. (2003). Permanent celibacy and late marriage in the Netherlands, 1890-1960. Population, 58(1), 69-102.

DOI: $10.3917 /$ popu.301.0069

Gellatly, C. (2015). Reconstructing historical populations from genealogical data files. In G. Bloothooft, P. Christen, K. Mandemakers, \& M. Schraagen (Eds.), Population Reconstruction (pp. 111-128). Cham: Springer International Publishing.

Hacker, J. D. (2010). Decennial life tables for the white population of the United States, 1790-1900. Historical methods, 43(2), 45-79.

DOI:10.1080/01615441003720449.

Haines, M.R. (1996). Long-term marriage patterns in the United States from colonial times to the present. History of the Family 1 (1), 15-39.

DOI: 10.1016/S1081-602X(96)90018-4

Hajnal, J. (1965). European marriage patterns in perspective. In D. Glass \& D. Eversley (Eds.), Population in History: Essays in Historical Demography (pp. 101-43). Chicago: Aldine Publishing Company.

Hayhoe, J. (2015). Strangers and Neighbours. Rural migration in eighteenth-century Northern Burgundy. Toronto: University of Toronto Press.

Jampaklay, A. (2006). How does leaving home affect marital timing? An event-history analysis of migration and marriage in Nang Rong, Thailand. Demography, 43(3), 48-66.

DOI: 10.1353/dem.2006.0035

Jonker, M. A., \& van der Vaart, A. W. (2007). Correcting missing-data bias in historical demography. Population studies, 61(1), 99-113.

DOI: $10.1080 / 00324720601048228$

Kok, J., Mandemakers, C.A.\& Mönkediek, B. (2014). Flight from the land? Migration flows of the rural population of the Netherlands, 1850-1940. Espaces Populations Sociétés, 1, 1-18.

DOI: 10.4000/eps.5631

Kuijpers, E. (2005). Migrantenstad: immigratie en sociale verhoudingen in 17e-eeuws Amsterdam. Hilversum: Uitgeverij Verloren.

Lynch, K. A. (1991). The European marriage pattern in the cities: Variations on a theme by Hajnal. Journal of Family History, 16(1), 79-96.

DOI: 10.1177/036319909101600106

Mandemakers, K. (2002). Building life course datasets from population registers by the Historical Sample of the Netherlands (HSN). History and Computing, 14(1-2), 87-107.

DOI: 10.3366/hac.2002.14.1-2.87

Mateos-Planas, X. (2002). The demographic transition in Europe: A neoclassical dynastic approach. Review of Economic Dynamics, 5,3, 646-680.

DOI: $10.1006 /$ redy.2001.0156

Moch, L. P. (1995). Moving Europeans: Historical migration practices in Western Europe. In R. Cohen (ed.), The Cambridge Survey of World Migration (pp. 126-130). Cambridge: Cambridge University Press.

Oris, M. (2000). The age at marriage of migrants during the industrial revolution in the region of Liège. The History of the Family, 5, 391-413. 
DOI: 10.1016/S1081-602X(00)00052-X

Poppel, F.W.A., van (1992). Trouwen in Nederland. Een historisch-demografische studie van de $19^{e}$ en vroeg-20 eeuw. The Hague: Netherlands Interdisciplinary Demographic Institute.

Poppel, F. van, Reher, D. S., Sanz-Gimeno, A., Sanchez-Dominguez, M., \& Beekink, E. (2012). Mortality decline and reproductive change during the Dutch demographic transition: Revisiting a traditional debate with new data. Demographic Research, 27, 299-338.

DOI: 10.4054/DemRes.2012.27.11

Puschmann, P., Grönberg, P., Schumacher R. \& Matthijs, K. (2014). Access to marriage and reproduction among migrants in Antwerp en Stockholm. A longitudinal approach to processes of social inclusion and exclusion, 1846-1926. The History of the Family, 19(1), 29-52.

DOI: $10.1080 / 1081602 X .2013 .796889$

Puschmann, P., Van den Driessche, N., Matthijs K. \& Van de Putte, B. (2016). Paths of acculturation and social inclusion. Migration, marriage opportunities and assortative mating by geographic origin in Antwerp, 1846-1920. Journal of Migration History, 2, 177-207.

DOI: 10.1163/23519924-00201007

Schmidt, A. \& van der Heijden, M. (2016). Women alone in early modern Dutch towns. Opportunities and strategies to survive. Journal of Urban History, 42(1), 21-38.

DOI: $10.1177 / 0096144215610771$

Shorter, E. (1975). The making of the modern family. New York: Basic Books.

Somerseth, H., Ekamper, P. and Sogner, S. (2016). Marriage patterns and residential behaviour among Norwegian women in Amsterdam, 1621-1720. Continuity and Change, 31(2), 175-209.

DOI: $10.1017 /$ S0268416016000217

Voland, E. \& Dunbar, R.I.M. (1997). The impact of social status and migration on female age at marriage in an historical population in north-west Germany. Journal of Biosocial Science, 29, 355-360.

Vries, J. de (1984). European Urbanization, 1500-1800. London: Routledge.

Zhao, Z. (2001). Chinese genealogies as a source for demographic research: A further assessment of their reliability and biases. Population Studies, 55(2), 181-193.

DOI: $10.1080 / 00324720127690$ 
Appendix A Evaluation of error and selection of the research database for the Dutch genealogical data

The files were evaluated for quality based on the following types of errors:

\section{No children:}

These files contained no children, either because they were dummy files or contained lists of individuals or places.

Parental age errors:

A parental age error occurred when a woman was $>60$ years old at the birth of a child and when a man was $>92$ years old, although it is recognised that there are some very rare cases where individuals have had children above these ages, notably, warnings were reported when a woman was $>55$ years old at the birth of a child and when a man was $>80$ years old.

Data integrity:

An error where a child was listed in a family, but no individual record existed for that child. This is a data integrity error, which can indicate data corruption or a parsing error, because the ID for an individual should not exist without a record.

Multiple parentage (where adoption tag was not present):

This error occurs when an individual is a child in more than one family and there is no adoption tag to indicate that the child was adopted.

Lifespan errors:

This error occurred if an individual died at age $<0$ or $>122$. Notably, a warning was reported for ages $>110$.

Events before birth:

An event occurring to an individual before birth, e.g. marriage, occupation, baptism resulted in an error.

Change of sex between birth and marriage:

Individuals born as males or females who then became wives or husbands, respectively, resulted in an error, although it is recognised that this could happen with same-sex marriages in modern data and not be regarded as an error. 
Appendix B Data tables

Table 1 Amsterdam marriages; genealogical data

\begin{tabular}{|c|c|c|c|c|c|c|}
\hline Half century & Sex $(\mathbf{1}=\mathbf{m})$ & $\mathbf{N}$ & Average age at marriage & hhhsd & se & ci \\
\hline $1650-99$ & 0 & 102 & 23.95 & 5.22 & 0.52 & 1.03 \\
\hline $1650-99$ & 1 & 92 & 27.75 & 6.40 & 0.67 & 1.33 \\
\hline $1700-49$ & 0 & 235 & 24.43 & 4.99 & 0.33 & 0.64 \\
\hline $1700-49$ & 1 & 228 & 27.11 & 6.02 & 0.40 & 0.79 \\
\hline $1750-99$ & 0 & 496 & 25.60 & 5.93 & 0.27 & 0.52 \\
\hline $1750-99$ & 1 & 473 & 27.37 & 5.91 & 0.27 & 0.53 \\
\hline $1800-49$ & 0 & 1,380 & 25.66 & 5.58 & 0.15 & 0.29 \\
\hline $1800-49$ & 1 & 1,402 & 27.29 & 6.12 & 0.16 & 0.32 \\
\hline $1850-99$ & 0 & 3,458 & 25.64 & 6.06 & 0.10 & 0.20 \\
\hline $1850-99$ & 1 & 3,246 & 27.21 & 6.02 & 0.11 & 0.21 \\
\hline
\end{tabular}

Table 2 Amsterdam marriages; Amsterdam marriage banns

\begin{tabular}{|c|c|c|c|c|c|c|}
\hline Half century & Sex $(\mathbf{1}=\mathbf{m})$ & $\mathbf{N}$ & Average age at marriage & sd & se & ci \\
\hline $1600-49$ & 0 & 8,341 & 24.63 & 4.66 & 0.05 & 0.10 \\
\hline $1600-49$ & 1 & 8,764 & 25.98 & 4.54 & 0.05 & 0.10 \\
\hline $1650-99$ & 0 & 16,265 & 25.86 & 5.54 & 0.04 & 0.09 \\
\hline $1650-99$ & 1 & 16,221 & 26.84 & 4.92 & 0.04 & 0.08 \\
\hline $1700-49$ & 0 & 17,647 & 27.49 & 6.23 & 0.05 & 0.09 \\
\hline $1700-49$ & 1 & 17,194 & 28.01 & 5.55 & 0.04 & 0.08 \\
\hline $1750-99$ & 0 & 17,645 & 27.64 & 6.55 & 0.05 & 0.10 \\
\hline $1750-99$ & 1 & 16,907 & 28.46 & 5.85 & 0.04 & 0.09 \\
\hline $1800-49$ & 0 & 4,616 & 27.12 & 6.79 & 0.10 & 0.20 \\
\hline $1800-49$ & 1 & 4,318 & 28.37 & 6.53 & 0.10 & 0.19 \\
\hline
\end{tabular}

Table 3 Netherlands marriages; genealogical data

\begin{tabular}{|c|c|c|c|c|c|c|}
\hline Half century & Sex $(\mathbf{1}=\mathbf{m})$ & $\mathbf{N}$ & $\begin{array}{c}\text { Average age at } \\
\text { marriage }\end{array}$ & sd & se & ci \\
\hline $1650-99$ & 0 & 1,317 & 24.37 & 5.56 & 0.15 & 0.30 \\
\hline $1650-99$ & 1 & 1,489 & 27.29 & 6.44 & 0.17 & 0.33 \\
\hline $1700-49$ & 0 & 3,281 & 24.69 & 5.43 & 0.09 & 0.19 \\
\hline $1700-49$ & 1 & 3,444 & 27.49 & 6.44 & 0.11 & 0.22 \\
\hline $1750-99$ & 0 & 11,465 & 25.15 & 5.44 & 0.05 & 0.10 \\
\hline $1750-99$ & 1 & 11,401 & 28.32 & 6.56 & 0.06 & 0.12 \\
\hline $1800-49$ & 0 & 55,289 & 25.31 & 5.66 & 0.02 & 0.05 \\
\hline $1800-49$ & 1 & 53,175 & 27.74 & 6.61 & 0.03 & 0.06 \\
\hline $1850-99$ & 0 & 103,407 & 25.84 & 5.96 & 0.02 & 0.04 \\
\hline $1850-99$ & 1 & 98,549 & 28.06 & 6.43 & 0.02 & 0.04 \\
\hline
\end{tabular}


Table 4 Netherlands marriages - North, South, East and West; genealogical data

\begin{tabular}{|c|c|c|c|c|c|c|c|}
\hline Half century & $\mathrm{E}, \mathrm{N}, \mathrm{S}, \mathrm{W}$ & $\operatorname{Sex}(1=m)$ & $\mathbf{N}$ & $\begin{array}{c}\text { Average age at } \\
\text { marriage }\end{array}$ & sd & se & ci \\
\hline $1650-99$ & $\mathrm{E}$ & 0 & 192 & 24.16 & 6.39 & 0.46 & 0.91 \\
\hline $1650-99$ & $\mathrm{E}$ & 1 & 240 & 28.01 & 6.90 & 0.45 & 0.88 \\
\hline $1650-99$ & $\mathrm{~N}$ & 0 & 135 & 23.13 & 4.97 & 0.43 & 0.85 \\
\hline $1650-99$ & $\mathrm{~N}$ & 1 & 162 & 27.74 & 6.42 & 0.50 & 1.00 \\
\hline $1650-99$ & $S$ & 0 & 205 & 24.55 & 5.28 & 0.37 & 0.73 \\
\hline $1650-99$ & $S$ & 1 & 249 & 27.85 & 6.20 & 0.39 & 0.77 \\
\hline $1650-99$ & W & 0 & 719 & 24.58 & 5.43 & 0.20 & 0.40 \\
\hline $1650-99$ & W & 1 & 772 & 26.94 & 6.34 & 0.23 & 0.45 \\
\hline $1700-49$ & $E$ & 0 & 632 & 24.65 & 5.50 & 0.22 & 0.43 \\
\hline $1700-49$ & $\mathrm{E}$ & 1 & 652 & 28.26 & 6.57 & 0.26 & 0.51 \\
\hline $1700-49$ & $\mathrm{~N}$ & 0 & 350 & 23.70 & 5.03 & 0.27 & 0.53 \\
\hline $1700-49$ & $\mathrm{~N}$ & 1 & 407 & 27.61 & 6.77 & 0.34 & 0.66 \\
\hline $1700-49$ & $S$ & 0 & 494 & 25.63 & 5.98 & 0.27 & 0.53 \\
\hline $1700-49$ & $S$ & 1 & 516 & 27.79 & 6.66 & 0.29 & 0.58 \\
\hline $1700-49$ & W & 0 & 1,728 & 24.66 & 5.34 & 0.13 & 0.25 \\
\hline $1700-49$ & W & 1 & 1,778 & 27.16 & 6.19 & 0.15 & 0.29 \\
\hline $1750-99$ & $E$ & 0 & 2,456 & 25.45 & 5.48 & 0.11 & 0.22 \\
\hline $1750-99$ & $\mathrm{E}$ & 1 & 2,476 & 29.23 & 6.62 & 0.13 & 0.26 \\
\hline $1750-99$ & $\mathrm{~N}$ & 0 & 2,118 & 24.79 & 5.32 & 0.12 & 0.23 \\
\hline $1750-99$ & $\mathrm{~N}$ & 1 & 2,088 & 28.41 & 6.66 & 0.15 & 0.29 \\
\hline $1750-99$ & $S$ & 0 & 1,386 & 25.80 & 4.99 & 0.13 & 0.26 \\
\hline $1750-99$ & $S$ & 1 & 1,385 & 28.88 & 6.50 & 0.17 & 0.34 \\
\hline $1750-99$ & W & 0 & 5,322 & 24.98 & 5.55 & 0.08 & 0.15 \\
\hline $1750-99$ & W & 1 & 5,260 & 27.75 & 6.42 & 0.09 & 0.17 \\
\hline $1800-49$ & $\mathrm{E}$ & 0 & 14,298 & 25.57 & 5.60 & 0.05 & 0.09 \\
\hline $1800-49$ & $\mathrm{E}$ & 1 & 13,796 & 28.46 & 6.53 & 0.06 & 0.11 \\
\hline $1800-49$ & $\mathrm{~N}$ & 0 & 9,460 & 25.28 & 5.73 & 0.06 & 0.12 \\
\hline $1800-49$ & $\mathrm{~N}$ & 1 & 9,119 & 27.81 & 6.72 & 0.07 & 0.14 \\
\hline $1800-49$ & $S$ & 0 & 5,840 & 26.54 & 5.80 & 0.08 & 0.15 \\
\hline
\end{tabular}


Table 5 Netherlands marriages - urban versus rural; genealogical data

\begin{tabular}{|c|c|c|c|c|c|c|c|}
\hline Half century & $\begin{array}{c}\text { Urban/rural } \\
\text { (urb. } \mathbf{1} \text { ) }\end{array}$ & Sex $(\mathbf{1}=\mathbf{m})$ & $\mathbf{N}$ & $\begin{array}{c}\text { Average age } \\
\text { at marriage }\end{array}$ & sd & se & ci \\
\hline $1650-99$ & 0 & 0 & 844 & 24.40 & 5.36 & 0.18 & 0.36 \\
\hline $1650-99$ & 0 & 1 & 981 & 27.15 & 6.29 & 0.20 & 0.39 \\
\hline $1650-99$ & 1 & 0 & 473 & 24.31 & 5.91 & 0.27 & 0.53 \\
\hline $1650-99$ & 1 & 1 & 508 & 27.58 & 6.71 & 0.30 & 0.59 \\
\hline $1700-49$ & 0 & 0 & 2,227 & 24.74 & 5.36 & 0.11 & 0.22 \\
\hline $1700-49$ & 0 & 1 & 2,381 & 27.52 & 6.39 & 0.13 & 0.26 \\
\hline $1700-49$ & 1 & 0 & 1,054 & 24.57 & 5.57 & 0.17 & 0.34 \\
\hline $1700-49$ & 1 & 1 & 1,063 & 27.41 & 6.57 & 0.20 & 0.40 \\
\hline $1750-99$ & 0 & 0 & 8,231 & 25.12 & 5.38 & 0.06 & 0.12 \\
\hline $1750-99$ & 0 & 1 & 8,248 & 28.52 & 6.56 & 0.07 & 0.14 \\
\hline $1750-99$ & 1 & 0 & 3,234 & 25.23 & 5.57 & 0.10 & 0.19 \\
\hline $1750-99$ & 1 & 1 & 3,153 & 27.82 & 6.53 & 0.12 & 0.23 \\
\hline $1800-49$ & 0 & 0 & 40,917 & 25.19 & 5.60 & 0.03 & 0.05 \\
\hline $1800-49$ & 0 & 1 & 39,311 & 27.89 & 6.56 & 0.03 & 0.06 \\
\hline $1800-49$ & 1 & 0 & 14,372 & 25.63 & 5.79 & 0.05 & 0.09 \\
\hline $1800-49$ & 1 & 1 & 13,864 & 27.29 & 6.72 & 0.06 & 0.11 \\
\hline $1850-99$ & 0 & 0 & 73,247 & 25.77 & 5.87 & 0.02 & 0.04 \\
\hline $1850-99$ & 0 & 1 & 69,839 & 28.30 & 6.44 & 0.02 & 0.05 \\
\hline $1850-99$ & 1 & 0 & 30,160 & 26.01 & 6.17 & 0.04 & 0.07 \\
\hline $1850-99$ & 1 & 1 & 28,710 & 27.46 & 6.39 & 0.04 & 0.07 \\
\hline
\end{tabular}

Table 6 Marriage age of Amsterdam born and elsewhere born individuals; Amsterdam marriage banns

\begin{tabular}{|c|c|c|c|c|c|c|c|}
\hline Half century & Place of origin & $\operatorname{Sex}(\mathbf{1}=\mathbf{m})$ & $\mathbf{N}$ & $\begin{array}{c}\text { Average age } \\
\text { at marriage }\end{array}$ & $\mathbf{s d}$ & $\mathbf{s e}$ & $\mathbf{c i}$ \\
\hline $1600-49$ & Amsterdam & 0 & 2,256 & 23.74 & 4.42 & 0.09 & 0.18 \\
\hline $1600-49$ & Amsterdam & 1 & 1,548 & 24.85 & 4.07 & 0.10 & 0.20 \\
\hline $1650-99$ & Amsterdam & 0 & 9,077 & 24.66 & 5.17 & 0.05 & 0.11 \\
\hline $1650-99$ & Amsterdam & 1 & 6,195 & 25.51 & 4.49 & 0.06 & 0.11 \\
\hline $1700-49$ & Amsterdam & 0 & 10,953 & 26.35 & 6.05 & 0.06 & 0.11 \\
\hline $1700-49$ & Amsterdam & 1 & 7,965 & 26.56 & 5.35 & 0.06 & 0.12 \\
\hline $1750-99$ & Amsterdam & 0 & 10,020 & 26.27 & 6.33 & 0.06 & 0.12 \\
\hline $1750-99$ & Amsterdam & 1 & 7,226 & 26.69 & 5.60 & 0.07 & 0.13 \\
\hline $1800-49$ & Amsterdam & 0 & 3,150 & 26.03 & 6.25 & 0.11 & 0.22 \\
\hline $1800-49$ & Amsterdam & 1 & 2,592 & 26.99 & 6.01 & 0.12 & 0.23 \\
\hline $1600-49$ & Elsewhere & 0 & 4,767 & 25.38 & 4.59 & 0.07 & 0.13 \\
\hline $1600-49$ & Elsewhere & 1 & 6,384 & 26.37 & 4.57 & 0.06 & 0.11 \\
\hline $1650-99$ & Elsewhere & 0 & 7,068 & 27.41 & 5.60 & 0.07 & 0.13 \\
\hline $1650-99$ & Elsewhere & 1 & 9,960 & 27.67 & 4.98 & 0.05 & 0.10 \\
\hline $1700-49$ & Elsewhere & 0 & 6,676 & 29.38 & 6.06 & 0.07 & 0.15 \\
\hline $1700-49$ & Elsewhere & 1 & 9,215 & 29.27 & 5.42 & 0.06 & 0.11 \\
\hline $1750-99$ & Elsewhere & 0 & 7,603 & 29.45 & 6.39 & 0.07 & 0.14 \\
\hline $1750-99$ & Elsewhere & 1 & 9,656 & 29.79 & 5.68 & 0.06 & 0.11 \\
\hline $1800-10$ & Elsewhere & 0 & 1,463 & 29.47 & 7.29 & 0.19 & 0.37 \\
\hline $1800-10$ & Elsewhere & 1 & 1,723 & 30.44 & 6.73 & 0.16 & 0.32 \\
\hline
\end{tabular}


Table 7 Marriage age of Amsterdam born and elsewhere born individuals; genealogical data

\begin{tabular}{|c|c|c|c|c|c|c|c|}
\hline Half century & Birth and marriage & $\operatorname{Sex}(1=m)$ & $\mathbf{N}$ & $\begin{array}{l}\text { Average age } \\
\text { at marriage }\end{array}$ & sd & se & $\mathrm{ci}$ \\
\hline $1650-99$ & bth_ams_marr_ams & 0 & 75 & 23.64 & 5.26 & 0.61 & 1.21 \\
\hline $1650-99$ & bth_ams_marr_ams & 1 & 43 & 28.12 & 7.14 & 1.09 & 2.20 \\
\hline $1650-99$ & bth_rur_marr_ams & 0 & 4 & 26.00 & 4.08 & 2.04 & 6.50 \\
\hline $1650-99$ & bth_rur_marr_ams & 1 & 9 & 26.56 & 4.42 & 1.47 & 3.40 \\
\hline $1650-99$ & bth_urb_marr_ams & 0 & 6 & 25.50 & 3.39 & 1.38 & 3.56 \\
\hline $1650-99$ & bth_urb_marr_ams & 1 & 15 & 26.40 & 3.60 & 0.93 & 1.99 \\
\hline $1700-49$ & bth_ams_marr_ams & 0 & 180 & 23.89 & 4.40 & 0.33 & 0.65 \\
\hline $1700-49$ & bth_ams_marr_ams & 1 & 142 & 25.92 & 5.99 & 0.50 & 0.99 \\
\hline $1700-49$ & bth_rur_marr_ams & 0 & 10 & 31.30 & 10.20 & 3.23 & 7.30 \\
\hline $1700-49$ & bth_rur_marr_ams & 1 & 20 & 29.30 & 5.07 & 1.13 & 2.37 \\
\hline $1700-49$ & bth_urb_marr_ams & 0 & 6 & 24.50 & 5.24 & 2.14 & 5.50 \\
\hline $1700-49$ & bth_urb_marr_ams & 1 & 15 & 29.27 & 5.98 & 1.54 & 3.31 \\
\hline $1750-99$ & bth_ams_marr_ams & 0 & 330 & 24.62 & 5.72 & 0.32 & 0.62 \\
\hline $1750-99$ & bth_ams_marr_ams & 1 & 284 & 26.12 & 5.20 & 0.31 & 0.61 \\
\hline $1750-99$ & bth_rur_marr_ams & 0 & 59 & 28.14 & 6.00 & 0.78 & 1.56 \\
\hline $1750-99$ & bth_rur_marr_ams & 1 & 44 & 28.95 & 3.99 & 0.60 & 1.21 \\
\hline $1750-99$ & bth_urb_marr_ams & 0 & 33 & 27.97 & 6.03 & 1.05 & 2.14 \\
\hline $1750-99$ & bth_urb_marr_ams & 1 & 41 & 27.54 & 5.55 & 0.87 & 1.75 \\
\hline $1800-49$ & bth_ams_marr_ams & 0 & 990 & 24.93 & 5.13 & 0.16 & 0.32 \\
\hline $1800-49$ & bth_ams_marr_ams & 1 & 889 & 26.32 & 5.43 & 0.18 & 0.36 \\
\hline $1800-49$ & bth_rur_marr_ams & 0 & 150 & 27.03 & 5.81 & 0.47 & 0.94 \\
\hline $1800-49$ & bth_rur_marr_ams & 1 & 138 & 29.03 & 7.49 & 0.64 & 1.26 \\
\hline $1800-49$ & bth_urb_marr_ams & 0 & 119 & 28.58 & 6.74 & 0.62 & 1.22 \\
\hline $1800-49$ & bth_urb_marr_ams & 1 & 143 & 28.00 & 6.61 & 0.55 & 1.09 \\
\hline $1850-99$ & bth_ams_marr_ams & 0 & 2,350 & 25.22 & 5.82 & 0.12 & 0.24 \\
\hline $1850-99$ & bth_ams_marr_ams & 1 & 2,048 & 26.51 & 5.75 & 0.13 & 0.25 \\
\hline $1850-99$ & bth_rur_marr_ams & 0 & 497 & 26.50 & 5.69 & 0.26 & 0.50 \\
\hline $1850-99$ & bth_rur_marr_ams & 1 & 541 & 28.16 & 5.78 & 0.25 & 0.49 \\
\hline $1850-99$ & bth_urb_marr_ams & 0 & 360 & 26.86 & 7.39 & 0.39 & 0.77 \\
\hline $1850-99$ & bth_urb_marr_ams & 1 & 400 & 28.34 & 5.96 & 0.30 & 0.59 \\
\hline
\end{tabular}


Table 8 East to West migration; genealogical data

\begin{tabular}{|c|c|c|c|c|c|c|c|c|}
\hline Half century & $\begin{array}{c}\text { Marriage } \\
\text { place }\end{array}$ & $\begin{array}{l}\text { Birth } \\
\text { place }\end{array}$ & $\begin{array}{c}\text { Sex } \\
(1=m)\end{array}$ & $\mathrm{N}$ & $\begin{array}{l}\text { Average age } \\
\text { at marriage }\end{array}$ & sd & se & ci \\
\hline $1650-99$ & E & E & 0 & 130 & 23.98 & 6.41 & 0.56 & 1.11 \\
\hline $1650-99$ & E & E & 1 & 165 & 28.22 & 6.89 & 0.54 & 1.06 \\
\hline $1650-99$ & $E$ & W & 0 & 4 & 29.75 & 13.52 & 6.76 & 21.52 \\
\hline $1650-99$ & E & W & 1 & 9 & 26.11 & 4.91 & 1.64 & 3.77 \\
\hline $1650-99$ & W & $E$ & 0 & 5 & 24.80 & 4.76 & 2.13 & 5.92 \\
\hline $1650-99$ & W & $E$ & 1 & 13 & 27.31 & 2.90 & 0.80 & 1.75 \\
\hline $1650-99$ & W & W & 0 & 546 & 24.42 & 5.58 & 0.24 & 0.47 \\
\hline $1650-99$ & W & W & 1 & 580 & 26.79 & 6.48 & 0.27 & 0.53 \\
\hline $1700-49$ & $E$ & $E$ & 0 & 476 & 24.23 & 5.12 & 0.23 & 0.46 \\
\hline $1700-49$ & E & E & 1 & 486 & 27.91 & 6.40 & 0.29 & 0.57 \\
\hline $1700-49$ & E & W & 0 & 9 & 25.33 & 4.24 & 1.41 & 3.26 \\
\hline $1700-49$ & E & W & 1 & 19 & 28.74 & 5.56 & 1.27 & 2.68 \\
\hline $1700-49$ & W & $E$ & 0 & 23 & 29.39 & 8.42 & 1.76 & 3.64 \\
\hline $1700-49$ & W & E & 1 & 38 & 28.24 & 6.28 & 1.02 & 2.06 \\
\hline $1700-49$ & W & W & 0 & 1,343 & 24.41 & 5.07 & 0.14 & 0.27 \\
\hline $1700-49$ & W & W & 1 & 1,316 & 26.74 & 6.08 & 0.17 & 0.33 \\
\hline $1750-99$ & $\mathrm{E}$ & E & 0 & 1,783 & 25.30 & 5.31 & 0.13 & 0.25 \\
\hline $1750-99$ & $\mathrm{E}$ & E & 1 & 1,819 & 29.11 & 6.61 & 0.16 & 0.30 \\
\hline $1750-99$ & $\mathrm{E}$ & W & 0 & 45 & 25.24 & 5.39 & 0.80 & 1.62 \\
\hline $1750-99$ & $E$ & W & 1 & 35 & 28.20 & 7.22 & 1.22 & 2.48 \\
\hline 1750-99 & W & $\mathrm{E}$ & 0 & 101 & 26.68 & 6.40 & 0.64 & 1.26 \\
\hline $1750-99$ & W & $\mathrm{E}$ & 1 & 127 & 28.91 & 5.79 & 0.51 & 1.02 \\
\hline 1750-99 & W & W & 0 & 4,132 & 24.75 & 5.45 & 0.08 & 0.17 \\
\hline $1750-99$ & W & W & 1 & 4,004 & 27.32 & 6.20 & 0.10 & 0.19 \\
\hline $1800-49$ & $E$ & $E$ & 0 & 11,344 & 25.47 & 5.46 & 0.05 & 0.10 \\
\hline $1800-49$ & $E$ & $E$ & 1 & 10,793 & 28.31 & 6.42 & 0.06 & 0.12 \\
\hline $1800-49$ & $\mathrm{E}$ & W & 0 & 394 & 25.87 & 6.82 & 0.34 & 0.68 \\
\hline $1800-49$ & $E$ & W & 1 & 503 & 28.37 & 6.45 & 0.29 & 0.56 \\
\hline $1800-49$ & W & $E$ & 0 & 566 & 27.52 & 6.21 & 0.26 & 0.51 \\
\hline $1800-49$ & W & $E$ & 1 & 579 & 29.35 & 7.22 & 0.30 & 0.59 \\
\hline $1800-49$ & W & W & 0 & 21,759 & 24.67 & 5.41 & 0.04 & 0.07 \\
\hline $1800-49$ & W & W & 1 & 20,436 & 26.64 & 6.18 & 0.04 & 0.08 \\
\hline $1850-99$ & $E$ & $E$ & 0 & 22,697 & 25.93 & 5.76 & 0.04 & 0.07 \\
\hline $1850-99$ & E & E & 1 & 20,991 & 28.60 & 6.37 & 0.04 & 0.09 \\
\hline $1850-99$ & $E$ & W & 0 & 743 & 27.07 & 6.83 & 0.25 & 0.49 \\
\hline $1850-99$ & $E$ & W & 1 & 1,130 & 29.52 & 7.03 & 0.21 & 0.41 \\
\hline $1850-99$ & W & $E$ & 0 & 1,327 & 27.14 & 6.43 & 0.18 & 0.35 \\
\hline $1850-99$ & W & $E$ & 1 & 1474 & 28.59 & 5.97 & 0.16 & 0.30 \\
\hline $1850-99$ & W & W & 0 & 42,128 & 25.26 & 5.81 & 0.03 & 0.06 \\
\hline $1850-99$ & W & W & 1 & 39,087 & 27.13 & 6.14 & 0.03 & 0.06 \\
\hline
\end{tabular}


Table 9 Urban (urb) and rural (rur) stayers (birth to marriage); genealogical data

\begin{tabular}{|c|c|c|c|c|c|c|c|}
\hline Half century & $\begin{array}{c}\text { Urban/rural birth } \\
\text { and marriage }\end{array}$ & $\begin{array}{c}\text { Sex } \\
(1=\mathrm{m})\end{array}$ & $\mathbf{N}$ & $\begin{array}{c}\text { Average age } \\
\text { at marriage }\end{array}$ & sd & se & ci \\
\hline $1650-99$ & rur_rur & 0 & 396 & 24.11 & 4.81 & 0.24 & 0.47 \\
\hline $1650-99$ & rur_rur & 1 & 451 & 26.89 & 6.28 & 0.30 & 0.58 \\
\hline $1650-99$ & urb_urb & 0 & 289 & 24.14 & 6.07 & 0.36 & 0.70 \\
\hline $1650-99$ & urb_urb & 1 & 261 & 26.98 & 6.28 & 0.39 & 0.77 \\
\hline $1700-49$ & rur_rur & 0 & 1,121 & 24.49 & 5.04 & 0.15 & 0.30 \\
\hline $1700-49$ & rur_rur & 1 & 1,174 & 27.10 & 5.91 & 0.17 & 0.34 \\
\hline $1700-49$ & urb_urb & 0 & 728 & 24.16 & 5.19 & 0.19 & 0.38 \\
\hline $1700-49$ & urb_urb & 1 & 607 & 26.33 & 6.08 & 0.25 & 0.48 \\
\hline $1750-99$ & rur_rur & 0 & 3,824 & 24.84 & 5.27 & 0.09 & 0.17 \\
\hline $1750-99$ & rur_rur & 1 & 3,657 & 28.23 & 6.42 & 0.11 & 0.21 \\
\hline $1750-99$ & urb_urb & 0 & 2,143 & 24.69 & 5.24 & 0.11 & 0.22 \\
\hline $1750-99$ & urb_urb & 1 & 1,899 & 27.15 & 6.27 & 0.14 & 0.28 \\
\hline $1800-49$ & rur_rur & 0 & 19,133 & 24.73 & 5.23 & 0.04 & 0.07 \\
\hline $1800-49$ & rur_rur & 1 & 17,074 & 27.43 & 6.37 & 0.05 & 0.10 \\
\hline $1800-49$ & urb_urb & 0 & 9,486 & 25.00 & 5.37 & 0.06 & 0.11 \\
\hline $1800-49$ & urb_urb & 1 & 8,514 & 26.41 & 6.18 & 0.07 & 0.13 \\
\hline $1850-99$ & rur_rur & 0 & 38,378 & 25.37 & 5.47 & 0.03 & 0.05 \\
\hline $1850-99$ & rur_rur & 1 & 30,820 & 27.92 & 6.16 & 0.04 & 0.07 \\
\hline $1850-99$ & urb_urb & 0 & 18,520 & 25.52 & 5.83 & 0.04 & 0.08 \\
\hline $1850-99$ & urb_urb & 1 & 16,304 & 26.70 & 5.98 & 0.05 & 0.09 \\
\hline
\end{tabular}


Table 10 Migration between urban and rural locations from birth to marriage; genealogical data

\begin{tabular}{|c|c|c|c|c|c|c|c|c|}
\hline Half century & $\operatorname{Sex}(1=m)$ & $\begin{array}{c}\text { Marr. place } \\
\text { urban/rural } \\
\text { (urb. =1) }\end{array}$ & $\begin{array}{c}\text { Birth place } \\
\text { urban/rural } \\
\text { (urb. = 1) }\end{array}$ & $\mathrm{N}$ & $\begin{array}{l}\text { Average age } \\
\text { at marriage }\end{array}$ & sd & se & ci \\
\hline $1650-99$ & 0 & 0 & 0 & 548 & 24.19 & 5.16 & 0.22 & 0.43 \\
\hline $1650-99$ & 0 & 0 & 1 & 35 & 24.94 & 6.81 & 1.15 & 2.34 \\
\hline 1650-99 & 1 & 0 & 0 & 676 & 27.17 & 6.37 & 0.24 & 0.48 \\
\hline $1650-99$ & 1 & 0 & 1 & 51 & 26.57 & 4.87 & 0.68 & 1.37 \\
\hline 1650-99 & 0 & 1 & 0 & 31 & 25.39 & 7.83 & 1.41 & 2.87 \\
\hline $1650-99$ & 0 & 1 & 1 & 322 & 24.01 & 5.91 & 0.33 & 0.65 \\
\hline $1650-99$ & 1 & 1 & 0 & 63 & 29.33 & 7.20 & 0.91 & 1.81 \\
\hline $1650-99$ & 1 & 1 & 1 & 317 & 27.21 & 6.72 & 0.38 & 0.74 \\
\hline $1700-49$ & 0 & 0 & 0 & 1,592 & 24.59 & 5.12 & 0.13 & 0.25 \\
\hline $1700-49$ & 0 & 0 & 1 & 82 & 24.24 & 5.66 & 0.62 & 1.24 \\
\hline $1700-49$ & 1 & 0 & 0 & 1,720 & 27.32 & 6.20 & 0.15 & 0.29 \\
\hline $1700-49$ & 1 & 0 & 1 & 117 & 28.43 & 7.56 & 0.70 & 1.38 \\
\hline $1700-49$ & 0 & 1 & 0 & 86 & 26.40 & 6.59 & 0.71 & 1.41 \\
\hline $1700-49$ & 0 & 1 & 1 & 781 & 24.18 & 5.26 & 0.19 & 0.37 \\
\hline $1700-49$ & 1 & 1 & 0 & 127 & 29.24 & 7.15 & 0.63 & 1.26 \\
\hline $1700-49$ & 1 & 1 & 1 & 694 & 26.70 & 6.21 & 0.24 & 0.46 \\
\hline 1750-99 & 0 & 0 & 0 & 6,178 & 25.00 & 5.30 & 0.07 & 0.13 \\
\hline 1750-99 & 0 & 0 & 1 & 263 & 25.51 & 6.26 & 0.39 & 0.76 \\
\hline 1750-99 & 1 & 0 & 0 & 6,103 & 28.39 & 6.47 & 0.08 & 0.16 \\
\hline 1750-99 & 1 & 0 & 1 & 341 & 28.22 & 7.10 & 0.38 & 0.76 \\
\hline 1750-99 & 0 & 1 & 0 & 376 & 26.28 & 5.52 & 0.28 & 0.56 \\
\hline 1750-99 & 0 & 1 & 1 & 2,332 & 24.81 & 5.44 & 0.11 & 0.22 \\
\hline 1750-99 & 1 & 1 & 0 & 415 & 29.22 & 6.55 & 0.32 & 0.63 \\
\hline 1750-99 & 1 & 1 & 1 & 2147 & 27.23 & 6.26 & 0.14 & 0.27 \\
\hline $1800-49$ & 0 & 0 & 0 & 33,727 & 25.08 & 5.50 & 0.03 & 0.06 \\
\hline $1800-49$ & 0 & 0 & 1 & 1,531 & 26.00 & 6.25 & 0.16 & 0.31 \\
\hline $1800-49$ & 1 & 0 & 0 & 31,842 & 27.72 & 6.41 & 0.04 & 0.07 \\
\hline $1800-49$ & 1 & 0 & 1 & 1,736 & 28.02 & 6.87 & 0.16 & 0.32 \\
\hline $1800-49$ & 0 & 1 & 0 & 2,326 & 26.80 & 6.16 & 0.13 & 0.25 \\
\hline $1800-49$ & 0 & 1 & 1 & 10,482 & 25.20 & 5.51 & 0.05 & 0.11 \\
\hline $1800-49$ & 1 & 1 & 0 & 2,333 & 28.34 & 7.00 & 0.14 & 0.28 \\
\hline $1800-49$ & 1 & 1 & 1 & 9,749 & 26.68 & 6.35 & 0.06 & 0.13 \\
\hline 1850-99 & 0 & 0 & 0 & 62,790 & 25.69 & 5.78 & 0.02 & 0.05 \\
\hline 1850-99 & 0 & 0 & 1 & 2,362 & 26.66 & 6.77 & 0.14 & 0.27 \\
\hline $1850-99$ & 1 & 0 & 0 & 58,168 & 28.22 & 6.35 & 0.03 & 0.05 \\
\hline 1850-99 & 1 & 0 & 1 & 3,312 & 28.64 & 6.88 & 0.12 & 0.23 \\
\hline 1850-99 & 0 & 1 & 0 & 5,965 & 26.79 & 6.48 & 0.08 & 0.16 \\
\hline 1850-99 & 0 & 1 & 1 & 20,958 & 25.72 & 6.02 & 0.04 & 0.08 \\
\hline 1850-99 & 1 & 1 & 0 & 6,121 & 28.29 & 6.54 & 0.08 & 0.16 \\
\hline 1850-99 & 1 & 1 & 1 & 19,435 & 27.04 & 6.16 & 0.04 & 0.09 \\
\hline
\end{tabular}


Table 11 Individuals and spouses who either stayed (st) or left (IV) their birth place between birth and marriage; genealogical data

\begin{tabular}{|c|c|c|c|c|c|c|c|}
\hline Half century & Focal sex $(1=m)$ & Stayers and leavers & $\mathbf{N}$ & $\begin{array}{l}\text { Average age } \\
\text { at marriage }\end{array}$ & sd & se & ci \\
\hline $1650-99$ & 0 & Iv_lv & 98 & 24.26 & 6.30 & 0.64 & 1.26 \\
\hline $1650-99$ & 0 & st_lv & 114 & 25.05 & 5.87 & 0.55 & 1.09 \\
\hline $1650-99$ & 0 & st_st & 331 & 23.85 & 5.31 & 0.29 & 0.57 \\
\hline $1650-99$ & 1 & Iv_lv & 104 & 27.63 & 6.37 & 0.62 & 1.24 \\
\hline $1650-99$ & 1 & st_lv & 66 & 26.94 & 5.47 & 0.67 & 1.34 \\
\hline $1650-99$ & 1 & st_st & 344 & 26.04 & 5.16 & 0.28 & 0.55 \\
\hline $1700-49$ & 0 & Iv_lv & 258 & 24.83 & 5.70 & 0.35 & 0.70 \\
\hline $1700-49$ & 0 & st_lv & 340 & 24.56 & 4.97 & 0.27 & 0.53 \\
\hline $1700-49$ & 0 & st_st & 961 & 24.34 & 5.21 & 0.17 & 0.33 \\
\hline $1700-49$ & 1 & Iv_lv & 257 & 28.46 & 7.44 & 0.46 & 0.91 \\
\hline $1700-49$ & 1 & st_lv & 224 & 26.58 & 5.43 & 0.36 & 0.71 \\
\hline $1700-49$ & 1 & st_st & 921 & 26.46 & 5.44 & 0.18 & 0.35 \\
\hline $1750-99$ & 0 & Iv_lv & 1,333 & 25.15 & 5.50 & 0.15 & 0.30 \\
\hline $1750-99$ & 0 & st_lv & 1,380 & 24.67 & 5.17 & 0.14 & 0.27 \\
\hline $1750-99$ & 0 & st_st & 3,131 & 24.64 & 5.18 & 0.09 & 0.18 \\
\hline $1750-99$ & 1 & Iv_lv & 1,276 & 28.58 & 6.54 & 0.18 & 0.36 \\
\hline $1750-99$ & 1 & st_lv & 1,070 & 28.55 & 6.75 & 0.21 & 0.40 \\
\hline $1750-99$ & 1 & st_st & 3,055 & 27.51 & 6.02 & 0.11 & 0.21 \\
\hline $1800-49$ & 0 & Iv_lv & 9,262 & 25.77 & 5.93 & 0.06 & 0.12 \\
\hline $1800-49$ & 0 & st_lv & 8,240 & 24.89 & 5.41 & 0.06 & 0.12 \\
\hline $1800-49$ & 0 & st_st & 14,610 & 24.58 & 5.02 & 0.04 & 0.08 \\
\hline $1800-49$ & 1 & Iv_lv & 8,858 & 28.43 & 6.95 & 0.07 & 0.14 \\
\hline $1800-49$ & 1 & st_lv & 6,411 & 27.54 & 6.67 & 0.08 & 0.16 \\
\hline $1800-49$ & 1 & st_st & 14,200 & 26.72 & 5.93 & 0.05 & 0.10 \\
\hline 1850-99 & 0 & Iv_lv & 16,601 & 26.57 & 6.61 & 0.05 & 0.10 \\
\hline $1850-99$ & 0 & st_lv & 18,395 & 25.68 & 5.77 & 0.04 & 0.08 \\
\hline $1850-99$ & 0 & st_st & 27,516 & 25.17 & 5.38 & 0.03 & 0.06 \\
\hline 1850-99 & 1 & Iv_lv & 15,507 & 28.93 & 7.12 & 0.06 & 0.11 \\
\hline 1850-99 & 1 & st_lv & 11,671 & 27.96 & 6.53 & 0.06 & 0.12 \\
\hline $1850-99$ & 1 & st_st & 26,570 & 27.20 & 5.87 & 0.04 & 0.07 \\
\hline
\end{tabular}


Table 12 Migration distance between birth and marriage, in categories $(0=0 \mathrm{~km}, 1=1-7 \mathrm{~km}, 2=$ $>7 \mathrm{~km})$; genealogical data

\begin{tabular}{|c|c|c|c|c|c|c|c|}
\hline Half century & $\operatorname{Sex}(1=m)$ & Migration cat. & $\mathrm{N}$ & $\begin{array}{l}\text { Average age } \\
\text { at marriage }\end{array}$ & sd & se & ci \\
\hline $1650-99$ & 0 & 0 & 685 & 24.12 & 5.37 & 0.21 & 0.40 \\
\hline $1650-99$ & 0 & 1 & 109 & 25.18 & 7.03 & 0.67 & 1.34 \\
\hline 1650-99 & 0 & 2 & 160 & 23.98 & 5.39 & 0.43 & 0.84 \\
\hline $1650-99$ & 1 & 0 & 711 & 26.95 & 6.28 & 0.24 & 0.46 \\
\hline 1650-99 & 1 & 1 & 140 & 27.53 & 6.50 & 0.55 & 1.09 \\
\hline 1650-99 & 1 & 2 & 283 & 28.11 & 6.89 & 0.41 & 0.81 \\
\hline $1700-49$ & 0 & 0 & 1849 & 24.37 & 5.10 & 0.12 & 0.23 \\
\hline $1700-49$ & 0 & 1 & 323 & 25.05 & 5.61 & 0.31 & 0.61 \\
\hline $1700-49$ & 0 & 2 & 415 & 24.78 & 5.61 & 0.28 & 0.54 \\
\hline $1700-49$ & 1 & 0 & 1,781 & 26.84 & 5.99 & 0.14 & 0.28 \\
\hline $1700-49$ & 1 & 1 & 342 & 27.72 & 7.10 & 0.38 & 0.75 \\
\hline $1700-49$ & 1 & 2 & 600 & 28.61 & 6.92 & 0.28 & 0.55 \\
\hline $1750-99$ & 0 & 0 & 5,954 & 24.79 & 5.26 & 0.07 & 0.13 \\
\hline 1750-99 & 0 & 1 & 1,469 & 25.10 & 5.10 & 0.13 & 0.26 \\
\hline 1750-99 & 0 & 2 & 1,879 & 25.75 & 5.92 & 0.14 & 0.27 \\
\hline 1750-99 & 1 & 0 & 5,539 & 27.87 & 6.40 & 0.09 & 0.17 \\
\hline 1750-99 & 1 & 1 & 1,493 & 28.47 & 6.71 & 0.17 & 0.34 \\
\hline 1750-99 & 1 & 2 & 2,208 & 28.70 & 6.40 & 0.14 & 0.27 \\
\hline $1800-49$ & 0 & 0 & 28,575 & 24.82 & 5.28 & 0.03 & 0.06 \\
\hline $1800-49$ & 0 & 1 & 8,513 & 25.33 & 5.69 & 0.06 & 0.12 \\
\hline $1800-49$ & 0 & 2 & 11,782 & 26.19 & 6.06 & 0.06 & 0.11 \\
\hline $1800-49$ & 1 & 0 & 25,538 & 27.08 & 6.31 & 0.04 & 0.08 \\
\hline $1800-49$ & 1 & 1 & 8,401 & 27.73 & 6.35 & 0.07 & 0.14 \\
\hline $1800-49$ & 1 & 2 & 12,621 & 28.45 & 6.81 & 0.06 & 0.12 \\
\hline 1850-99 & 0 & 0 & 56,751 & 25.41 & 5.58 & 0.02 & 0.05 \\
\hline 1850-99 & 0 & 1 & 13,462 & 26.00 & 6.11 & 0.05 & 0.10 \\
\hline 1850-99 & 0 & 2 & 22,896 & 26.66 & 6.51 & 0.04 & 0.08 \\
\hline 1850-99 & 1 & 0 & 46,939 & 27.49 & 6.12 & 0.03 & 0.06 \\
\hline 1850-99 & 1 & 1 & 14,478 & 28.23 & 6.51 & 0.05 & 0.11 \\
\hline $1850-99$ & 1 & 2 & 27,050 & 28.74 & 6.66 & 0.04 & 0.08 \\
\hline
\end{tabular}

